\title{
Współczesne problemy gerontologiczne $w$ kontekście cywilizacyjnych przemian
}

Współczesna cywilizacja przesiąknięta jest kultem techniki, a skuteczność i szybkość realizacji potrzeb stały się priorytetem. Dla wielu konsumpcja stanowi przepustkę do lepszego, szczęśliwego świata. Świat konsumpcji rozumiany jest jako rzeczywistość, w której każde pragnienie musi zostać natychmiast zaspokojone, żadna chęć nie może być frustrowana. To świat rozrywki polegającej przede wszystkim na „satysfakcji płynącej z konsumowania i wchtaniania towarów, widoków, potraw, napojów, papierosów, ludzi, wykładów, książek, filmów [...]. Świat jest jednym wielkim przedmiotem naszego apetytu [...]; jesteśmy wiecznie oczekującymi, wiecznie pełnymi nadziei i wiecznie rozczarowa-

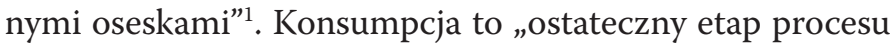
gospodarowania polegającego na przyswajaniu czy też zużywaniu dóbr i usług w celu zaspokojenia wszelkiego rodzaju ludzkich potrzeb”2.

Omawiane zjawiska mają dodatkowo jeszcze jedną ważną cechę. Jest nią globalizacja, która może być oceniana bardzo różnorodnie. Wiadomo bowiem, iż „globalizacja zakłada ideę społeczności światowej, ale jej nie stwarza; taka

1 E. Fromm, Zdrowe społeczeństwo, tłum. A. Tanalska-Dulęba, Warszawa 1996, s. 171-172.

2 L. Hostyński, Wartości w świecie konsumpcji, Lublin 2006, s. 12. 
społeczność jest sygnalizowana tak samo przez globalizację zjawisk negatywnych, jak i przez wpływy integracyjne"3.

Jednym z takich niepokojących problemów związanych z globalizacją zjawisk społecznych jest miejsce osób starszych we współczesnym świecie. Otaczający nas świat niejednokrotnie „ukrywa” ze wstydem kwestie starzejącego się społeczeństwa. Miał tego świadomość Jan Paweł II, kiedy w 2002 roku pisał: „Doświadczenie uczy, że brak tego pozytywnego nastawienia sprzyja marginalizacji ludzi starszych i skazuje ich na samotność porównywalną do prawdziwej śmierci społecznej. A czyż mniemanie, jakie człowiek starszy ma o sobie, nie zależy w dużej mierze od uwagi, jaką poświęca mu rodzina i społeczeństwo"?4

\section{Współczesne problemy seniorów}

W kontekście powyższych zjawisk należy wymienić przynajmniej dziewięć problemów natury gerontologicznej, które warto szerzej omówić. Zaliczyć do nich można: juwenizm, marginalizację osób starszych, samotność, „ekonomiczną eutanazję", problemy przemocowe, samobójstwa i depresje osób starszych, problemy w pełnieniu ról przez starszych, ich aktywizację oraz problemy religijne wieku starczego.

\section{Juwenizm}

Juwenizm właściwy współczesnej kulturze masowej odrzuca starość jako zarówno niewygodną, jak i wstydli-

A. Giddens, Poza prawica i lewica, tłum. J. Serwański, Poznań 1994, s. 93.

4 Jan Paweł II, List papieski do uczestników II Światowego Zgromadzenia poświęconego problemom starzenia się ludności, „L'Osservatore Romano" 23 (2002) nr 6, s. 6. 
wą rzeczywistość. To jakby kres konsumpcji uważanej za „akt zaspokojenia potrzeby człowieka w wyniku zużywania dóbr materialnych i usług" ". Juwenizm staje się wręcz „ideologią", w której kult cielesności, młodzieżowy styl życia oraz kanon zachowania cool są wyznacznikami nowoczesności danego człowieka czy społeczeństwa.

Trzeba także pamiętać, że propagowany kult młodości niesie ze sobą pogoń za sprawnością, efektywnością i umiejętnością urządzania się w życiu, wypierając dojrzałą refleksję. Ludzie starsi, zwłaszcza gorzej wykształceni, czują się coraz bardziej obco w tak szybko zmieniającym się świecie.

Okazuje się, że „zjawisko poczucia braku sensu życia u starszej generacji jest czymś dotychczas niespotykanym i stanowi wynik przeobrażeń cywilizacyjnych (o czym już pisała M. Mead), jak i triumfu juwenizmu, filozofii młodości, lansowanej przez mass media. Utrata znaczenia, autorytetu, niezdolność przystosowania się do szybkich zmian - to wszystko prowadzi starsze pokolenie do utraty wiary w siebie i odczucia bezwartościowości”. Oczywiście nie można na ten problem patrzeć tendencyjnie, bowiem - jak mówił w 1999 roku Jan Paweł II - „w społeczeństwach o wysokim poziomie rozwoju przemysłowego i technicznego położenie ludzi starszych jest dwuznaczne: z jednej strony są oni coraz słabiej wszczepieni w tkankę rodzinną i społeczną, z drugiej zaś odgrywają coraz ważniejszą rolę zwłaszcza jako opiekunowie i wychowawcy wnuków. Dla młodych małżeństw obecność «dziadków» jest często niezbędną pomocą. Z jednej strony zatem człowiek starszy jest spychany na margines, z drugiej zaś - jest potrzebny. Wszystko to wskazuje na brak równowagi typowy dla modelu społecznego podporządkowanego prawom

C. Bywalec, L. Rudnicki, Konsumpcja, Warszawa 2002, s. 15.

B. Truchlińska, Myśl antropologiczno-aksjologiczna Viktora E. Frankla, „Parerga” 2005 nr 2, s. 138. 
ekonomii i zysku, który ma tendencję do dyskryminacji «nieproduktywnych» członków społeczeństwa, gdyż bardziej zwraca uwagę na przydatność człowieka niż na jego wartość samoistną"”.

W kontekście rozważanych problemów gerontologicznych warto wymienić przynajmniej kilka zjawisk związanych z lansowanym obecnie juwenizmem. Oto one:

- Ludzie starzy są odbierani w sposób stereotypowy jako bezproduktywni, których społeczeństwo musi utrzymać. Takie podejście budzi u osób starszych poczucie bycia balastem oraz „złem koniecznym”. Świadomość tego niesie ze sobą rozczarowanie środowiskiem oraz negatywne podejście do starości. To z kolei może budzić frustrację.

- Kult młodości generuje wiele refleksji związanych z sensem życia oraz „przydatnością społeczną”. Lansowana przez media afirmacja kanonów piękna, urody czy zdrowia sprawia, że człowiek stary odczuwa jeszcze bardziej skutki upływającego czasu.

- Juwenizm otwiera drogę do negowania znaczenia i mądrości starszego pokolenia. W konsekwencji rodzi to wśród ludzi starszych poczucie niewdzięczności i żalu do młodszych pokoleń. Z jednej strony może pojawić się rozczarowanie tymi, dla których starsi przez lata pracowali, z drugiej natomiast - niezdrowy krytycyzm wobec ludzi młodych. W ten sposób pogłębia się konflikt międzypokoleniowy.

- Przesadne kreowanie młodości prowadzi do retrospektywnego spojrzenia osób starszych na otaczającą rzeczywistość. Wspomnienia połączone z tęsknotą za poprzednim okresem życia powodują wzrost poziomu nieakceptacji aktualnego stanu rzeczy. W takiej sytuacji

Jan Paweł II, Rozważanie przed modlitwą „Anioł Pański” (Castel Gandolfo, 25.07.1999), „L'Osservatore Romano” 20 (1999) nr 11, s. 49. 
cierpienie - zarówno to fizyczne, psychiczne, jak i duchowe - staje się jeszcze większe, a perspektywa przyszłości coraz bardziej się zawęża.

- Przeciwstawianie młodości i starości powoduje także niepokojący wzrost lęku przed wiekiem starczym. Starość kojarzy się z przemijaniem, niedołęstwem, samotnością i czekaniem na śmierć. Pod wpływem takiego myślenia młodzi próbują zatrzymać czas. Starsi coraz częściej mają wpajane podejście defetystyczne wobec swojego wieku, kondycji, celów i znaczenia.

- Pod wpływem juwenizmu starość staje się tematem tabu, bowiem kojarzy się z jakimś końcem. Jest to ucieczka przed zadawaniem sobie pytań o sens życia, o jego wartość, a także o kres. W tym kontekście ludzie starsi coraz bardziej wierzą w stereotypy typu: „Człowiek jest skazany na starość” lub „Jedyna rzecz, jaka nie udała się Bogu, to starość".

Z pewnością świadom był tych wszystkich problemów papież Franciszek, kiedy na początku pontyfikatu mówił do kardynałów: „Drodzy bracia, odwagi! Połowa z nas jest w podeszłym wieku: starość jest - jak lubię ją określać - okresem mądrości życia. Starzy ludzie obdarzeni są mądrością, bo przeszli w życiu długą drogę, jak starzec Symeon, jak stara Anna w świątyni. I właśnie ta mądrość pozwoliła im rozpoznać Jezusa. Obdarzajmy tą mądrością młodych: jak dobre wino, które z upływem lat staje się coraz lepsze, obdarzajmy młodych życiową mądrością. Przychodzą mi na myśl słowa niemieckiego poety o starości: «Es ist ruhig, das Alter, und fromm»: jest to czas spokoju i modlitwy. I również dawania młodym tej mądrości”8.

Współczesne społeczeństwa muszą na nowo przemyśleć swoje preferencje, bowiem odcinanie się od ludzi starych, tworzących przecież historię narodu, jest drogą donikąd.

8 Papież Franciszek, Audiencja dla kardynałów (15.03.2013), „L’Osservatore Romano" 34 (2013) nr 5, s. 11. 
Co więcej - jak mówił papież Franciszek - „starsi ludzie to ci, którzy niosą nam historię, którzy niosą nam nauczanie i wiarę, zostawiają nam spuściznę. Oni jak stare wino; mają wewnętrzną siłę, by przekazać nam szlachetne dziedzictwo. [...] Naród, który nie opiekuje się dziadkami i nie szanuje ich, nie ma przyszłości, bo nie ma pamięci, stracił ją"

Warto na koniec zaznaczyć, że juwenizm „w odsłonie polskiej” może prowadzić do stereotypu, w którym „starość utożsamiana jest z wizją klęski. Brak odpowiedniej edukacji powoduje, że na nieuniknioną starość patrzy się z lękiem. Istnieje obawa, że nastąpi rozwój współczesnej gerontofobii, czyli wrogiego uczucia do ludzi starszych, przejawiającego się obojętnością, brakiem zrozumienia dla osób wymagających opieki, pomocy i miłości. O starości mówi się jako o zniedołężnieniu, schorowaniu, potrzebie korzystania z pomocy innych. Takie nastawienie, niemające uzasadnienia w dotychczasowej wiedzy na temat specyfiki procesu starzenia się, niekorzystnie wpływa zarówno na kształtowanie społecznych postaw wobec starości, jak i na samopoczucie tych, którzy przekroczyli próg wieku emerytalnego"10. Nie ma wątpliwości, że każdy powinien przyłączyć się do likwidacji szkodliwego juwenizmu, który w konsekwencji prowadzi do marginalizacji ludzi starych.

\section{Marginalizacja osób starszych}

Trudno nie zgodzić się z poglądem, iż „powiększają się przeszkody, na które ciągle napotykają ludzie starsi, począwszy od wspomnianych barier architektonicznych, poprzez psychologiczne - urzędnicy i lekarze są nieprzy-

9 Papież Franciszek, Homilia w czasie mszy świętej w domu św. Marty (19.11.2013), http://gosc.pl/doc/1784844.Papiez-Ludzie-starsi-sa-zrodlem-madrosci (16.02.2014).

10 P. Kocimska, Starość wyzwaniem dla wspótczesności, „Niebieska Linia" 2003 nr 5, s. 6. 
gotowani do kontaktów z ludźmi starymi - aż do barier technologicznych - nowoczesnych technologii, które lekceważą specyficzne wymagania ludzi starych. Na przykład klawiatury komórek są za małe dla niezbyt sprawnych palców ich rąk, a obsługa zbyt skomplikowana. Zbyt niskie emerytury i renty sprawiają, że starsi ludzie zmuszeni są do kupowania najtańszych produktów, ale także uniemożliwiają im chodzenie do kina, teatru, kawiarni czy restauracji"11. Na tym m.in. polega marginalizacja osób starszych, którzy są niejako wyrzuceni poza nawias aktywności społecznej.

W 2004 roku Jan Paweł II przypominał i ostrzegał: „Wiele osób w podeszłym wieku nie ma wystarczających środków do życia lub odpowiednich zasiłków. Niektóre z nich są chore, inne czują się już niepotrzebne bądź wstydzą się tego, że potrzebują szczególnej opieki, a zbyt liczne czują się po prostu opuszczone. Te kwestie będą nabierać coraz większej wagi, ponieważ liczba osób starszych wciąż rośnie, a społeczeństwo starzeje się na skutek spadku przyrostu naturalnego"12.

Owa marginalizacja wynika z zapatrzenia się na człowieka sprawnego, pełnego werwy, zdrowego. Jak pisze znany pisarz, dziennikarz i publicysta, Jerzy Surdykowski, „wyścig za młodością jest oczywiście po trosze objawem narcyzmu, a po trosze gonitwą baranów ogłupionych przez reklamę. Ale wynika też z zapatrzenia w siebie, jakie jest cechą współczesnej cywilizacji. Ukierunkowanie na «ja» - i to jeszcze «ja» na modłę telenoweli - musi prowadzić do panicznego strachu przed starzeniem"13.

Owo zapatrzenie jest źródłem marginalizacji seniorów. Jest ona związana ze zjawiskiem zwanym ageizmem. Ro-

11 T. Miłek, Niekochana starość, „Przewodnik Katolicki” 2006 nr 40, s. 6.

12 Jan Paweł II, Do uczestników sesji plenarnej Papieskiej Akademii Nauk Społecznych (30.04.2004), „L’Osservatore Romano” 25 (2004) nr 7-8, s. 17.

13 J. Surdykowski, Starość, „Znak” 2007 nr 3, s. 140. 
zumie się przez niego „zestaw przekonań, uprzedzeń i stereotypów mających swe podstawy w biologicznym zróżnicowaniu ludzi, związanym z procesem starzenia się, które dotyczą kompetencji i potrzeb osób w zależności od ich chronologicznego wieku"14.

Okazuje się, że w Polsce to zjawisko jest niezmiernie często spotykane ${ }^{15}$. Na rynku pracy przejawia się ono m.in. poprzez:

- inne traktowanie pracowników w zależności od wieku (starszy człowiek jest szybciej zwalniany);

- podawanie w ogłoszeniach o pracę maksymalnego wieku („zatrudnię osobę w wieku do 40 lat” lub „zatrudnię osobę młodą");

- rzadsze delegowanie starszych pracowników na szkolenia czy wybieranie dla nich tańszych i krótszych kursów; niezapewnienie świadczeń medycznych osobom starszym, ograniczenie dostępu do badań i programów profilaktycznych;

- brak systemowej opieki geriatrycznej dedykowanej osobom w wieku podeszłym ${ }^{16}$.

Jednym z wymiarów związanych z marginalizacją jest fakt, że „we współczesnych czasach kultu i dominacji młodości ludzie niechętnie określają siebie jako osoby stare i próg starości odczytywany z autoidentyfikacji jest inny niż w pytaniach ogólnych i kierowanych do całej zbiorowości"17. Marginalizacja powoduje, że senior staje się coraz bardziej nieobecny, traci swoją pozycję społeczną, w której mógłby

14 P. Szukalski, Uprzedzenia i dyskryminacja ze względu na wiek (ageizm) - przyczyny, przejawy, konsekwencje, „Polityka Społeczna” 2004 nr 2, s. 11.

15 P. Szukalski, Solidarność pokoleń. Dylematy relacji międzypokoleniowych, Łódź 2012, s. 139-178.

16 S. Krupińska, S. Tobis, A. Jakrzewska-Sawińska, K. Wieczorkowska-Tobis, Dlaczego boimy się starości?, „Geriatria” 2013 nr 7, s. 21.

17 J. Osiecka-Chojnacka, Społeczne opinie o starości a wdrażanie idei aktywnego starzenia się, „Studia BAS” 2012 nr 2, s. 107. 
osiągać określone cele ${ }^{18}$. Owa marginalizacja związana jest generalnie z określonymi problemami wieku starszego, które można pogrupować w cztery kategorie zdrowotne, społeczno-egzystencjalne, finansowe, związane z dostępem do infrastruktury ${ }^{19}$. To z kolei prowadzi do dyskryminacji seniorów.

Jak pisze Justyna Osiecka-Chojnacka, „najistotniejsze czynniki sprzyjające dyskryminacji to brak kultury i właściwego wychowania osób młodszych oraz brak wiedzy o potrzebach i ograniczeniach związanych z podeszłym wiekiem. Miejsca, w których respondenci doświadczają i obserwują tego rodzaju zachowania, to komunikacja miejska, ale też instytucje służby zdrowia i urzędy"20.

We współczesnej gerontologii mówi się przynajmniej o kilku przejawach dyskryminacji osób starszych, co w konsekwencji prowadzi do marginalizacji:

- unikanie bliskich kontaktów z osobami starszymi;

- upowszechnianie przekonań o negatywnych cechach ludzi starszych;

- utrwalanie w postaci aktów prawnych negatywnego stereotypu seniorów, pozbawiając ich określonych praw;

- izolowanie jednostek lub całych grup osób starszych od środowiska społecznego;

- biologiczne wyniszczanie ludzi ${ }^{21}$.

Ponadto, jak wskazują badania, „protekcjonalne traktowanie starych ludzi wywołuje ich poczucie niekompetencji i dążenie do wycofania. Jako skutek pojawiają się: zaniżona samoocena, depresja i zachowania wskazujące na zależność od innych. Protekcjonalne traktowanie innych nie musi być przejawem złych intencji, jest to niekiedy brak

18 Por. M. Kuchcińska, Edukacja przeciw marginalizacji seniorów, "Chowanna” 52 (2009) t. 2 (33), s. 177.

19 Por. J. Osiecka-Chojnacka, Społeczne opinie o starości, dz. cyt., s. 108.

20 Tamże, s. 113.

21 Por. A. A. Zych, Stownik gerontologii społecznej, Warszawa 2001, s. 60 . 
znajomości lub lekceważenie rutynowych form, które respektują zasady życzliwości i szacunku, np. nie pozwalają do starszej osoby mówić bezosobowo lub per „babciu”. W Polsce lekceważenie zasad, by nie powiedzieć pogardliwy stosunek wobec starszych, widać także w społecznym przyzwoleniu na „żarty” typu: „uratuj kraj”, „zabierz babci dowód” czy stosowanie określenia „moherowe berety”22.

„Dyskryminacja nie jest rzecz jasna przestępstwem, choć w dosyć prosty sposób do czynów karalnych może prowadzić, jak we wszystkich zachowaniach opartych na «fobicznych», motywowanych zwykle strachem, uprzedzeniach. Ogląd rzeczywistości pokazuje, że dyskryminacja ze względu na wiek dosyć często łączy się z innymi uprzedzeniami, prowadząc do tzw. dyskryminacji wielokrotnej. Osoby starsze nie są bowiem pozbawione także innych cech «niepożądanych» lub «nieszanowanych» społecznie - płeć (kobieta), niepełnosprawność, orientacja seksualna (nieheteroseksualna), wyznanie religijne (lub jego brak), narodowość, przynależność do grupy etnicznej itd." ${ }^{23}$.

Trzeba też pamiętać, że marginalizacja osób starszych wpływa na jakość ich życia, kondycję psycho-duchową. Osoby starsze przestają mieć dostęp do zachowań, cech i umiejętności, które są społecznie cenione. Powstaje tzw. mechanizm błędnego koła. Niesie on ze sobą dodatkowo postawę automarginalizacji i pogłębienie się stereotypowego postrzegania starości.

Warto w tym miejscu przypomnieć, że powyższe kwestie poruszał w swoim liście do osób starszych Jan Paweł II. Pisał jednoznacznie, że „ludzie starzy pomagają nam mądrzej patrzeć na ziemskie wydarzenia, ponieważ dzięki życiowym doświadczeniom zyskali wiedzę i dojrzałość. Są strażnikami pamięci zbiorowej, a więc mają szczególny tytuł,

22 J. Osiecka-Chojnacka, Społeczne opinie o starości, dz. cyt., s. 113.

23 R. Durda, Dyskryminacja i przemoc wobec osób starszych, www.spr. org.pl/(20.02.2014). 
Rys. 1. Mechanizm błędnego koła, w którym negatywny obraz starości przekłada się na gorszą sprawność

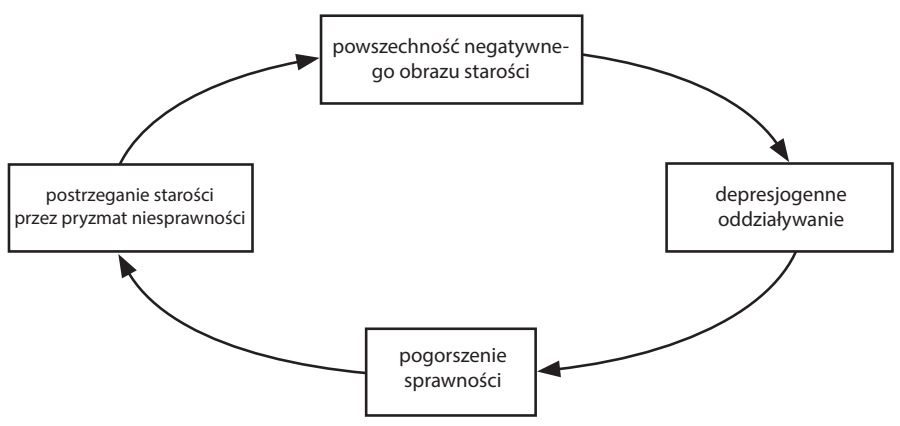

Źródło: S. Krupińska, S. Tobis, A. Jakrzewska-Sawińska, K. Wieczorkowska-Tobis, Dlaczego boimy się starości?, „Geriatria” (2013) nr 7, s. 22.

aby być wyrazicielami wspólnych ideałów i wartości, które są podstawą i regułą życia społecznego. Wykluczyć ich ze społeczeństwa znaczy w imię nowoczesności pozbawionej pamięci odrzucić przeszłość, w której zakorzeniona jest teraźniejszość. Ludzie starsi dzięki swej dojrzałości i doświadczeniu mogą udzielać młodym rad i cennych pouczeń" ${ }^{24}$.

Nie ma żadnej wątpliwości, że marginalizacja oraz dyskryminacja osób starszych prowadzi w konsekwencji do samotności seniorów, a w dalszej perspektywie do pogorszenia się ich stanu zdrowotnego. Samotność osób starszych to kolejne współczesne, wręcz globalne wyzwanie.

\section{Samotność osób starszych}

Trudno nie zgodzić się z poglądem, że „początek starości jest rozmyty, trudny do ustalenia zarówno w dyskursie naukowym, jak i w rozumieniu potocznym. Symbolicznym wejściem w starość bywa przejście na emeryturę, ale początek tego etapu kojarzony jest również z byciem samotnym,

24 Jan Paweł II, List do moich Braci i Sióstr - ludzi w podeszłym wieku, Kraków 1999, 10. 
zepchniętym na margines" ${ }^{25}$. I rzeczywiście, wiele osób starszych odczuwa samotność mającą wieloczynnikowe źródła. Trzeba też zaznaczyć, że „samotność jest czynnikiem zagrażającym rozwojowi osobowości jednostki. Problem polega na tym, że samotność ogranicza przeżywanie pozytywnych emocji, sprzyja rozwojowi postawy egocentrycznej, jest powodem nadmiernego egotyzmu, powoduje izolację społeczną i wycofanie, przy czym człowiek ma tendencję do nadmiernego wyolbrzymiania problemów"26.

William Sadler, jeden z wybitnych badaczy problematyki samotności, wyróżnił pięć rodzajów samotności:

- samotność interpersonalna (to tęsknota do kogoś lub za kimś, np. z powodu utraty bliskiej osoby);

- samotność społeczna (odczuwanie odizolowania od ludzi lub odrzucenia przez określoną grupę lub wspólnotę społeczną);

- samotność kulturowa (odczuwanie odmienności w stosunku do zwyczajowego, tradycyjnego sposobu życia);

- samotność kosmiczna (odczuwanie bezsensu własnej egzystencji, bycia poza sensem i znaczeniem życia);

- samotność psychologiczna (odczuwanie wyobcowania się z ważnej, istotnej części swojego ja ${ }^{27}$.

Niezależnie od tego, która samotność z powyższej typologii jest analizowana, należy stwierdzić, że „w świetle dotychczasowej wiedzy o uwarunkowaniach poczucia osamotnienia zależy ona od następujących czynników: stanu cywilnego, dzietności, typu zamieszkania, przynależności społeczno-zawodowej (przed przejściem na emeryturę), stanu zdrowia, sprawności fizycznej, jakości opieki

25 B. Krupa, Starość w percepcji młodzieży-perspektywa pedagogiczna, „Nowiny Lekarskie” 81 (2012) nr 1, s. 37.

26 E. Dubas, Edukacja dorostych w sytuacji samotności i osamotnienia, Łódź 2000, s. 51.

27 Por. W. Sadler, The causes of loneliness, [w:] Psychology and personal growth, red. A. Arkoff, Boston 1988, s. 136. 
świadczonej przez rodzinę, oceny sytuacji materialnej oraz od jakości więzi łączących człowieka starego z rodziną"28.

Istnieją także cztery postaci osamotnienia, które mogą wpływać na otoczenie (również na przemoc):

- osamotnienie charakterystyczne dla ludzi, którzy utracili bliską osobę lub zerwali z nią kontakt;

- osamotnienie spowodowane niezaspokojeniem potrzeb podmiotu przez ludzi, z którymi utrzymuje kontakt;

- osamotnienie będące konsekwencją długotrwałej samotności i powodujące przygnębienie i depresję;

- osamotnienie będące efektem niezadowolenia z istniejących kontaktów społecznych, które prowadzą do poczucia znudzenia i rozczarowania ${ }^{29}$.

Trzeba pamiętać, że rzeczywistość samotności jest dla seniorów szczególnie bolesna, bowiem „starość jest okresem traumatycznym dla człowieka, zwłaszcza w świecie szybkich przemian cywilizacyjnych oraz wobec wielu zagrożeń. Zdaniem psychologów człowiek lepiej znosi trudne sytuacje wówczas, jeżeli istnieje perspektywa korzystnych zmian. W okresie starości - w ostatniej fazie życia - takiej perspektywy często już się nie dostrzega, dlatego wiele zdarzeń krytycznych wpływa na osobę w starszym wieku wyjątkowo stresogennie. Starość to rodzaj wyzwania dla jednostki, która musi się zmagać z nieuchronną naturą biologii i jest uwikłana w liczne zdarzenia kryzysowe, wpisane zwłaszcza w ten okres życia" ${ }^{30}$.

Analizując współczesne badania gerontologiczne, można pokusić się o podanie podstawowych przyczyn odczuwanej samotności przez seniorów. Oto one:

28 A. Kotlarska-Michalska, Starość w aspekcie socjologicznym, „Roczniki Socjologii Rodziny" 2000 nr 12, s. 155.

29 Por. B. Hołyst, Na granicy życia i śmierci, Warszawa 2007, s. 365.

30 H. Zielińska-Więczkowska, K. Kędziora-Kornatowska, T. Kornatowski, Starość jako wyzwanie, „Gerontologia Polska” 16 (2008) nr 3, s. 132. 
- fakt śmierci współmałżonka, co prowadzi do przerwania naturalnych relacji małżeńskich, a także braku zaspokojenia potrzeb emocjonalnych;

- problemy materialne po odejściu jednego z małżonków;

- następstwa rozpadu rodziny wielopokoleniowej: zakładanie przez dzieci osobnych gospodarstw domowych, częste osobne zamieszkiwanie;

- ograniczenie kontaktów społecznych w związku z przejściem na emeryturę lub ze względu na zły stan zdrowia;

- izolacja społeczna związana z funkcjonowaniem stereotypowego obrazu starości;

- nadmiar czasu wolnego ${ }^{31}$.

Mówiąc o samotności osób starszych, trzeba także wspomnieć o sposobach radzenia sobie z nią. „Samotna osoba starsza może przystosować się do tego stanu w sposób pozytywny lub negatywny. Do pozytywnych form przystosowania się do samotności zaliczamy: wolontariat, intensyfikację spotkań ze znajomymi, zajęcie się hobby, uczęszczanie na zajęcia organizowane przez uniwersytety trzeciego wieku, uczęszczanie na zajęcia organizowane przez dzienne centra pomocy, spisywanie wspomnień $\mathrm{w}$ formie pamiętnika. Wolontariat świadczony przez osoby starsze może być skierowany do ich mniej sprawnych rówieśników lub do dzieci”32.

Nie można też zapomnieć o wspomaganiu seniorów w samotności przez wspólnotę wierzących. Benedykt XVI w sposób jednoznaczny nauczał, że „Kościół ze swojej strony zawsze bardzo szanował osoby starsze. Czwarte przykazanie: «Czcij swego ojca i swoją matkę, jak ci nakazał Pan» (Pwt 5, 16) wiąże się z obietnicą: «abyś długo żył

31 E. Miszczak, Problem samotności i osamotnienia wśród ludzi starszych $w$ Polsce, [w:] Życie w starości, red. B. Bugajska, Szczecin 2007, s. 281-284.

32 J. Plak, Różne oblicza samotności seniora, „Pedagogia Ojcostwa” 2012 nr 5 (1), s. 261. 
i aby ci się dobrze powodziło na ziemi, którą ci daje Pan, Bóg twój» (tamże). To dzieło Kościoła na rzecz osób starszych i chorych nie tylko zapewnia im miłość i opiekę, ale jest także wynagradzane przez Boga błogosławieństwami, obietnicą ziemi, na której Jego przykazanie jest wypełniane. Bóg pragnie, aby godność, wartość, zdrowie i dobrobyt osób starszych były należycie szanowane, a Kościół poprzez swoje instytucje charytatywne w Wielkiej Brytanii i innych krajach stara się wypełniać przykazanie Pana, nakazujące szanowanie życia bez względu na wiek czy stan zdrowia"33.

Seniorzy starają się także sami radzić sobie z samotnością, co w niektórych sytuacjach nie jest dla nich korzystne. Okazuje się, że „do negatywnych form przystosowania do starości możemy zaliczyć: izolację, wycofanie się z życia społecznego; zamknięcie się w swoim świecie/domu; stworzenie własnej, alternatywnej rzeczywistości (fikcyjny przyjaciel) oraz życie przeszłością. Takie formy są najczęściej wybierane przez osoby, dla których zakończenie aktywności zawodowej lub utrata bliskiej osoby stały się jednocześnie momentem, w którym ich życie straciło sens"34.

W kontekście powyższych refleksji powstaje pytanie: jak społeczeństwo może pomóc osobom starszym w radzeniu sobie z osamotnieniem i samotnością? Wydaje się, że rację ma Paulina Dąbrowska, kiedy twierdzi, że „warto uświadamiać sobie i młodemu pokoleniu, jak istotną rolę osoba starsza pełni w rodzinie. To właśnie dziadkowie są skarbnicą wiedzy, tradycji, pamięci o historii. Dlatego warto szukać jak najwięcej dróg komunikacji międzypokoleniowej:

- pytać o wspomnienia starszych osób, o historię rodziny, o wydarzenia historyczne, w których brali udział;

33 Benedykt XVI, Wizyta w Domu św. Piotra (Londyn, 18.09.2010), „L'Osservatore Romano” 31 (2010) nr 11, s. 35.

34 J. Plak, Różne oblicza samotności seniora, dz. cyt., s. 261. 
- rozmawiać z osobami starszymi o tym, co się obecnie dzieje, wprowadzać je w bieżące problemy, opowiadać o współczesnej rzeczywistości, pomagać osobom starszym w funkcjonowaniu w technologicznej rzeczywistości: pomagać oswoić się z komórką, kartą płatniczą czy z komputerem (Internetem)" 35 .

Aktualne zdaje się być przesłanie papieża Benedykta XVI, który przypominał każdej chrześcijańskiej rodzinie: „Niech dziadkowie znów będą aktywnie obecni w rodzinach, w Kościele i w społeczeństwie. Gdy chodzi o rodziny, niech dziadkowie nadal pełnią w nich rolę świadków jedności, wartości opartych na wierności jedynej miłości, która rodzi wiarę i radość życia. Tak zwane nowe modele rodziny i szerzący się relatywizm osłabiły te podstawowe wartości komórki rodzinnej. Jak słusznie zauważyliście podczas waszych obrad - pilnie potrzeba środków zaradczych na plagi naszego społeczeństwa. Czy w obliczu kryzysu rodziny pierwszym krokiem nie mogłoby być właśnie wykorzystanie obecności i świadectwa dziadków - tych, którzy mają silniej ugruntowane wartości i wizje życia? Nie można bowiem planować przyszłości bez odwoływania się do przeszłości, bogatej w istotne doświadczenia oraz duchowe i moralne punkty odniesienia. Gdy myślimy o dziadkach, o ich świadectwie miłości i wierności życiu, przypominają się biblijne postacie Abrahama i Sary, Elżbiety i Zachariasza, Joachima i Anny, a także starców Symeona i Anny czy również Nikodema: wszyscy oni przypominają nam, że w każdym okresie życia Pan domaga się od każdego, by jego talenty przynosiły pożytek"36.

35 P. Dąbrowska, Samotność osób starszych $i$ sposoby jej przeciwdziatania, „Fides et Ratio” 2011 nr 2 (6), s. 90.

36 Benedykt XVI, Do uczestników XVIII Zgromadzenia Plenarnego Papieskiej Rady ds. Rodziny (15.04.2008), „L'Osservatore Romano” 29 (2008) nr 5, s. 29. 


\section{„Ekonomiczna eutanazja”}

Senior wraz z wiekiem staje się człowiekiem coraz bardziej bezbronnym. Co więcej, może odczuwać świadomość bycia obciążeniem dla społeczeństwa. Pojawia się bowiem coraz częściej przyzwolenie dla ideologii śmierci, w której eutanazja zajmuje szczególne miejsce. A przecież „eutanazja, a nawet tylko myślowa jej akceptacja przez lekarzy, oznacza całkowite odwrócenie celów i systemu wartości”37. Człowiek stary, nie tylko schorowany, jest potencjalną ofiarą owej ideologii.

I tak, „gdyby Jan Paweł II dostał się w ręce holenderskich lekarzy, mogliby oni uznać, że jako człowiek schorowany i pozbawiony bliskiej rodziny nie powinien dłużej żyć i się męczyć. Chyba że, jak jeden z tysięcy holenderskich emerytów, nosiłby przy sobie paszport życia. To wyraźne oświadczenie, że jego właściciel nie zgadza się na eutanazję, gdyby na przykład zasłabł na ulicy i nieprzytomny trafił do szpitala"38.

Nie ma wątpliwości, że eutanazja staje się niezwykle niebezpiecznym trendem społecznym, ale i etycznym w XXI wieku. Wprawdzie w Polsce eutanazja jest niedozwolona, ale „obserwując spustoszenie, jakie powoduje wdrożona w Polsce reforma służby zdrowia, powstaje obawa, czy nie zostanie rozpowszechniona w naszym kraju «ekonomiczna eutanazja», czyli świadome zaniechanie działania zarówno diagnostycznego, jak i terapeutycznego $\mathrm{z}$ powodu braku środków finansowych. Zredukowany budżet większości jednostek służby zdrowia powoduje oszczędności dotykające szczególnie chorych z niepomyślnym rokowaniem i wymagających stosowania

37 R. Fenigsen, Eutanazja. Śmierć z wyboru?, Poznań 1994, s. 104.

38 M. Cieślik, W. Górny, M. Bogdasiński, Eutanazizm, „Wprost” 2004, nr 13, s. 58. 
kosztownych procedur (np. dializoterapia, skomplikowane zabiegi chirurgiczne)" ${ }^{\prime 3}$.

Można pokusić się o podanie podstawowych przejawów omawianej „eutanazji ekonomicznej”, rozumianej jako wymuszone skracanie życia przez sytuację ekonomiczną osób starszych.

\section{Wymiary „eutanazji ekonomicznej”}

1. Niemożność wykupienia lekarstw ze względu na brak środków finansowych będących w zasięgu osób starszych.

2. Ze względów ekonomicznych niemożność korzystania z zabiegów oraz leczenia w sektorze prywatnym służby zdrowia.

3. W wielu przypadkach brak możliwości po 60 . roku życia skorzystania z nowoczesnych sposobów terapii (np. nowotworowych).

4. Pogarszająca się stopniowo jakość życia, wynikająca z braków środków do życia.

5. Pomaganie dzieciom i wnukom, co rujnuje budżet seniorów.

6. Brak perspektyw na poprawę sytuacji ekonomicznej osób starszych.

7. Manipulacje wokół ubezpieczeń społecznych, które nie dają pewności dotyczącej finansowego zabezpieczenia leczenia.

8. Coraz większe kolejki do lekarzy specjalistów, co zmniejsza szanse na skuteczne leczenie.

9. Zniechęcające do życia prognozy dotyczące przyszłości seniorów (starzejące się społeczeństwo, którego nie stać na świadczenia społeczne).

39 T. M. Zielonka, Na marginesie Kodeksu Etyki Lekarskiej, „Gazeta Lekarska" 2000 nr 3, s. 20. 
10. Ukryta inflacja sprawiająca, że utrzymanie staje się coraz droższe (nie wystarcza środków na leczenie).

11. Brak spójnej polityki społecznej, dającej seniorom poczucie bezpieczeństwa.

12. Brak radości z życia ze względu na niewystarczające środki finansowe przeznaczane na wspomaganie aktywności w zakresie ogólnie pojętej kultury (także tej fizycznej).

13. Poczucie wykluczenia społecznego wynikającego $\mathrm{z}$ biedy (poczucie wstydu oraz tendencje do automarginalizacji).

14. Powtarzające się myśli samobójcze wynikające z braku środków do życia i na leczenie się.

15. wybieranie przez osoby starsze i niepełnosprawne śmierci (idea „right-to-die”), z obawy przed finansowym obciążaniem swoich bliskich.

Źródło: opracowanie własne.

Z drugiej strony wiadomo już od wielu lat, że „bez przesunięcia odpowiedzialności za jakość życia odchodzących na emerytury na nich samych, na ich rodziny i bliskich - aktywni zawodowo nie zdołają unieść obciążeń fiskalnych"40. U schyłku XX wieku Jan Paweł II, któremu osoby starsze były szczególnie bliskie, przypominał: „Nie można bowiem pogodzić się z faktem, że ograniczenia środków ekonomicznych, przejawiające się dziś na różne sposoby, faktycznie pogarszają przede wszystkim sytuację słabszych grup społecznych i uboższych obszarów świata, pozbawiając je niezbędnej opieki lekarskiej. Nie do przyjęcia jest również to, że w następstwie owych ograniczeń pozbawia się tej opieki ludzi znajdujących się

40 E. Trafiałek, Polska starość $w$ dobie przemian, Katowice 2003, s. 83. 
w pewnych okresach życia lub sytuacjach, w których są oni szczególnie bezbronni lub słabi, takich jak na przykład okres przed narodzeniem, starość, ciężka choroba, choroby śmiertelne" ${ }^{41}$.

„Ekonomiczna eutanazja” jest niestety porażką cywilizacyjną, bowiem „kiedy postęp medyczny i inne czynniki sprawiają, że wzrasta długowieczność, ważne staje się uznanie, że obecność rosnącej liczby osób starszych jest dla społeczeństwa błogosławieństwem. Każde pokolenie może się wiele nauczyć, korzystając z doświadczeń i mądrości pokolenia, które je poprzedziło. Oczywiście opieka nad osobami starszymi powinna być traktowana nie tyle jako akt wielkoduszności, ile jako spłacenie długu wdzięczności” ${ }^{42}$. W przeciwnym razie „ekonomiczna eutanazja" wpisze się w zjawisko biedy społecznej, która doprowadzi do omówionej wyżej ekskluzji społecznej. Empiryczne powiązania pomiędzy biedą a wykluczeniem społecznym, mogące prowadzić od „ekonomicznej eutanazji”, przedstawia schemat (rys. 2) - owoc badań Ruth Lister.

Dobrym podsumowaniem dotychczasowych refleksji mogą być słowa Benedykta XVI, który w sposób zdecydowany przypominał w 2010 roku, że „z wielu stron, niestety, coraz bardziej narasta «kultura śmierci», która jest zagrożeniem również dla trzeciego wieku. Dochodzi wręcz do tego, że proponuje się z coraz większym naciskiem eutanazję jako sposób rozwiązania niektórych trudnych sytuacji. Starość i jej problemy, związane również z nowymi sytuacjami rodzinnymi i społecznymi, będącymi konsekwencją nowoczesnego rozwoju, powinny być traktowane

41 Jan Paweł II, Do uczestników XIV Międzynarodowej Konferencji Papieskiej Rady ds. Duszpasterstwa Służby Zdrowia (19.11.1999), „L'Osservatore Romano” 21 (2000) nr 2, s. 43.

42 Benedykt XVI, Wizyta w Domu św. Piotra (Londyn, 18.09.2010), dz. cyt., s. 35. 
Rys. 2. Empiryczne związki pomiędzy biedą a wykluczeniem społecznym

\section{Przyczynowe / sekwencyjne}

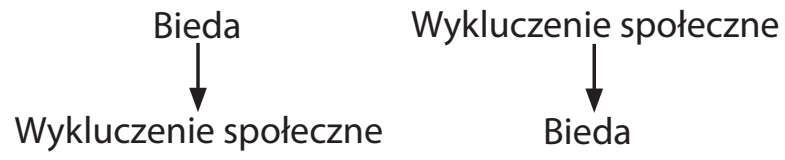

\section{Deskrypcyjne}

Zawarte w sobie

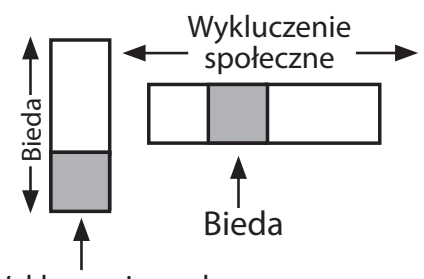

Wykluczenie społeczne
Zachodzące na siebie

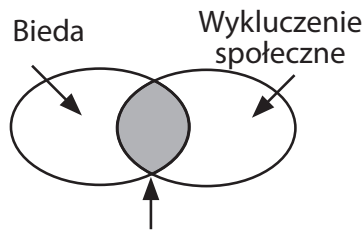

Bieda i wykluczenie społeczne

Źródło: R. Lister, Bieda, tłum. A. Stanaszek, Warszawa 2007, s. 105, za: P. Kubicki, Ubóstwo $i$ wykluczenie społeczne osób starszych. Ekspertyza przygotowana w ramach projektu „EAPN Polska - razem na rzecz Europy Socjalnej”, http:// www.eapn.org.pl/wp-content/uploads/2013/07/Ubostwo-i-wykluczenie-oso\%C5\%82b-starszych.pdf.

z rozwagą i zawsze w świetle prawdy o człowieku, o rodzinie i o wspólnocie. Trzeba zawsze mocno reagować na to, co odczłowiecza społeczeństwo. Ta problematyka domaga się wyraźnej odpowiedzi ze strony wspólnot parafialnych i diecezjalnych, które starają się zaradzać nowym potrzebom osób starszych. Istnieją stowarzyszenia i ruchy kościelne, które poświęciły się tej ważnej i niecierpiącej zwłoki sprawie. Trzeba połączyć siły, aby razem przeciwstawić się wszelkim formom spychania na margines, bowiem ofiarami mentalności indywidualistycznej są nie tylko oni - dziadkowie, babcie, osoby starsze - lecz wszyscy. Jeżeli - jak często i z wielu stron się słyszy - dziadkowie są 
cennym skarbem, trzeba podejmować konsekwentne decyzje, które pozwolą jak najlepiej go wykorzystać"43.

\section{Problemy przemocowe}

Warto w tym miejscu jeszcze raz uświadomić sobie, że starzenie się jest „nieuchronnym, powszechnym, długotrwałym, zróżnicowanym, wielopłaszczyznowym i naturalnym procesem, zależnym od człowieka i od czynników społecznych, ekonomicznych, biologicznych, psychologicznych, ekologicznych, historycznych i kulturowych" ${ }^{\prime 4}$. Dodatkowo należy stwierdzić fakt, że „nigdy chyba świat nie był tak sprzymierzony przeciw starszej generacji jak obecnie, nigdy też pozycja człowieka starego nie była tak niska. Zawrotne tempo życia, burzliwy rozwój nauki i przemysłu, natłok informacji, kult techniki i siły, hołdowanie rekordom i młodości, hedonistyczny duch cywilizacji - oto warunki, które czynią współczesne życie coraz trudniejszym dla jednostek starych i słabych"45.

Ta trudna sytuacja seniorów jest potęgowana przez poszerzające się zjawisko przemocy rozumianej jako „pojedyncze lub powtarzające się działanie, lub brak odpowiedniego działania, występujące w jakiejkolwiek relacji, w której oczekuje się zaufania, a która powoduje krzywdę bądź cierpienie osoby starszej. Może ona przybierać różne formy: przemocy fizycznej, psychicznej, seksualnej, finansowej, a także formę intencjonalnego lub nieintencjonalnego zaniedbania (definicja podana za The Toronto Declaration on the Prevention of Elder Abuse)" ${ }^{46}$.

43 Benedykt XVI, Do uczestników XVIII Zgromadzenia Plenarnego Papieskiej Rady ds. Rodziny (15.04.2008), dz. cyt., s. 28.

44 D. Zaworska-Nikoniuk, Obszary zainteresowań pedagogów społecznych, Olsztyn 2002, s. 254.

45 B. Synak, Starość w obliczu wspótczesnych przemian społeczno-kulturowych, [w:] Człowiek w obliczu starości, red. W. Pałubicki, Gdańsk 1991, s. 5.

46 Z poradnika „Przemoc wobec osoby starszej”, www.kampaniaprzemoc.pl/przemoc_wobec_osob_starszych.php (15.02.2014). 
Warto wymienić podstawowe wymiary owej przemocy, w Polsce można zauważyć funkcjonowanie „deskryptywnej normy stosowania przemocy (przynajmniej) wobec osób starszych. Nie jest ona zaleceniem, jak należy się do osób starszych odnosić, ale przedstawia „normalny” (w rozumieniu statystycznym) stan rzeczy. Konsekwencją istnienia takiej normy byłaby większa łatwość usprawiedliwiania stosowania przemocy wobec osób starszych" ${ }^{\prime 7}$. Oto przejawy przemocy wobec seniorów.

\section{Najczęstsze przejawy przemocy wobec seniorów:}

\section{Przemoc fizyczna}

- zadawanie bólu poprzez bicie, popychanie, wykręcanie rąk itp.;

- głodzenie;

- zamykanie w domu w samotności;

- pozbawianie snu.

\section{Przemoc psychiczna}

- zadawanie bólu poprzez obniżanie wartości osoby starszej;

- pozbawianie sensu życia;

- pozbawianie poczucia bezpieczeństwa (poprzez agresję);

- seksualne wykorzystywanie (np. spełnianie obowiązku małżeńskiego pod przymusem).

\section{Przemoc ekonomiczna}

- wykorzystanie finansowe;

- odbieranie renty czy emerytury;

- zmuszanie do zmiany testamentu.

\section{Przemoc instytucjonalna}

- nadużycia w urzędach;

47 Przemoc $w$ rodzinie wobec osób starszych $i$ niepetnosprawnych. Raport z badania ogólnopolskiego (zespół projektu pod kierunkiem dr. hab. K. Korzeniowskiego), Warszawa 2009, s. 80. 
- marginalizacja na rynku pracy;

- bagatelizowanie spraw seniorów.

\section{Zaniedbanie}

- brak troski o zaspokojenie potrzeb fizycznych i psychicznych;

- reglamentowanie czasu na rozmowę i obecność innych;

- zaniedbywanie czynności pielęgnacyjnych;

- zaniedbania dotyczące skutecznego leczenia.

Źródło: opracowanie własne.

Oczywiście, powstaje pytanie o uwarunkowania przemocy wobec seniorów. Co ciekawe, w wyniku badań można wysnuć hipotezę, że „wyłączenie z aktywnego stylu życia, rutynizacja codziennej aktywności kształtują u osoby starszej cechy potencjalnej ofiary przemocy. Do takich cech charakterystycznych należą: słabość a tym samym dostępność dla sprawcy, atrakcyjność z racji zakumulowanego bogactwa, samotność i bezradność"48. Ponadto z badań wynika, że część społeczeństwa usprawiedliwia przemoc wobec seniorów. Okazuje się, że „analiza psychologicznych uwarunkowań symptomów przemocy w rodzinie pozwoliła wyróżnić dwa rozłączne modele dotyczące usprawiedliwiania przemocy oraz obojętności na przemoc. Usprawiedliwianie przemocy okazało się powiązane z «darwinistyczną» wizją świata społecznego. Przede wszystkim jednak jest silnie uwarunkowane częstością kontaktów z aktami przemocy (szczególnie w środowisku rodzinnym). Ludzie odrzucają przemoc wobec osób starszych i niepełnosprawnych jako zachowanie moralnie naganne głównie wtedy, gdy nie mają z nią bezpośredniej styczności i jest ona dla nich zjawiskiem abstrakcyjnym.

48 E. Sygit, R. Ossowski, Przemoc wobec osób starszych ze względu na ich wiek, płeć $i$ wykształcenie, „Geriatria Polska” 2008 nr 3, s. 164. 
Ich rygoryzm moralny maleje, kiedy przemoc staje się dla nich realnym doświadczeniem" ${ }^{\prime 4}$.

Z badań wynika także, że najczęściej owo przyzwolenie, a w konsekwencji działania przemocowe mają miejsce w obszarze psychicznym. Sprawcami przemocy są częściej osoby obce niż członkowie rodziny ${ }^{50}$. W rodzinie funkcjonuje natomiast postawa obojętności wobec osoby starszej. Ta obojętność „nie jest powiązana częstością kontaktów z aktami przemocy. Jest za to bardzo wyraźnie uwarunkowana przez niektóre rysy mentalności psychospołecznej. Obojętności sprzyja:

- poczucie anomii - objawiające się odrzucaniem społecznie akceptowanych norm moralnych lub dezorientacją względem tego, «co jest dobre, a co złe»;

- autorytarny światopogląd - przejawiający się uległością wobec siły i przewagi oraz hołdujący konwencjonalnym truizmom kulturowym (m.in. przekonaniu, iż nie należy «wtrącać się» w sprawy innych);

- materializm - orientacja na wartości materialne, której towarzyszy przedmiotowe traktowanie ludzi w kategoriach bezosobowych i instrumentalnych" 51 .

Jak widać, problem przemocy wobec osób starszych jest wyzwaniem dla współczesnej cywilizacji. Trzeba pamiętać, że seniorzy - ofiary przemocy rzadko proszą o pomoc. Powstrzymuje je od tego uczucie wstydu, lęk przed opiekunem, obawa przed umieszczeniem w DPS lub poczucie winy. Może się więc okazać, że seniorzy próbują odreagować, a przez to sami stają się agresywni.

W świetle badań agresja seniorów jest najczęściej konsekwencją strachu, niezaspokojenia potrzeb, nieumiejętności

49 Przemoc $w$ rodzinie wobec osób starszych $i$ niepetnosprawnych..., dz. cyt., s. 84 .

50 Por. A. Grzanka-Tykwińska, A. Rzepka, M. Chudzińska, B. Sygit, K. Kusza, K. Kedziora-Kornatowska, Problematyka przemocy wobec osób starszych, „Nowiny Lekarskie” 81 (2012) nr 1, s. 47.

51 Przemoc $w$ rodzinie wobec osób starszych $i$ niepetnosprawnych..., dz. cyt., s. 84-85. 
odnalezienia się w nowej sytuacji życiowej lub spadku funkcji kontrolnych. W tym zjawisku najważniejsze są następujące czynniki:

- zależność, bezradność, spadek zręczności;

- zanik racjonalnego myślenia, spadek kompetencji komunikacyjnych;

- strach przed śmiercią, osamotnienie;

- poczucie krzywdy (rzeczywiste lub urojone);

- irytacja ze względu na nakazy;

- irytacja ze względu na ograniczenie swobody, poczucie zagrożenia;

- zazdrość;

- niemożność napicia się alkoholu (zapalenia papierosa), nadużywanie alkoholu;

- leki;

- złe warunki bytowe;

- błędy opiekunów, niechęć do opiekuna „winnego” nieobecności rodziny;

- niechęć do opiekuna podobnego do nielubianej osoby;

- manipulacja mająca na celu ściągnięcie rodziny;

- wcześniejsza skłonność do zachowań agresywnych, irytujące otoczenie;

- bezsenność, ból, choroba ${ }^{52}$.

Na koniec można ukazać źródła potencjału przemocy. Schemat ukazujący owe źródła przedstawia rys. 3.

\section{Samobójstwa i depresje osób starszych}

Nie ma wątpliwości, że „w wielu doniesieniach badawczych wskazuje się na duże rozpowszechnienie depresji (30-60\%) oraz niepokojący wzrost samobójstw w populacji osób w starszym wieku. W grupie seniorów powyżej 75. roku życia notuje się najwyższy wskaźnik samobójstw

52 Por. E. Jaroszewska, Starość i agresja - osoby starsze jako ofiary oraz sprawcy przemocy, „Problemy Polityki Społecznej” 2012 nr 17, s. 122. 
Rys. 3. Źródła potencjału przemocy ${ }^{53}$

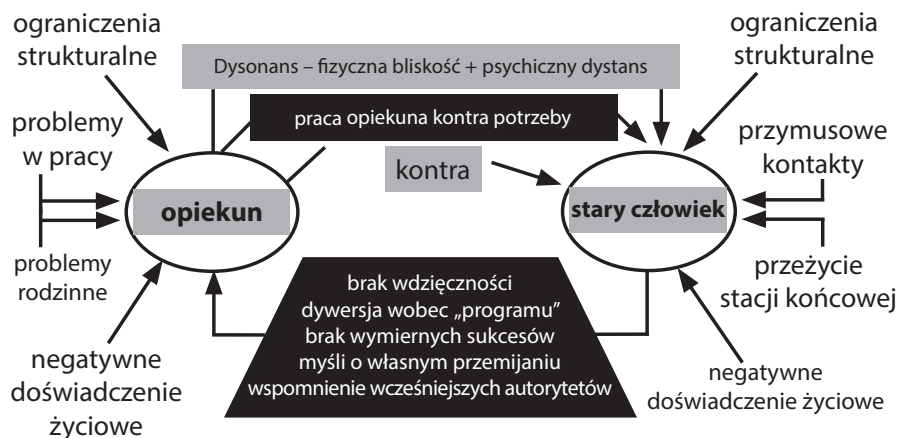

Źródło: Gewalt in der Pflege: ein drängendes gesellschaftliches Problem, [w:] R. D. Hirsch, Handeln statt Mißhanden - Bonner Initiative gegen Gewalt im Alter, Bonn 2000, s. 19.

spośród wszystkich grup wiekowych, i to w większości krajów uprzemysłowionych. Fakt ten bezspornie dowodzi o tym, że wiele osób w podeszłym wieku nie jest przygotowanych do okresu starości"54. Samobójstwo osoby starszej w większości przypadków jest związane z depresją starczą. Ryzyko depresji wzrasta wraz z wiekiem. Nie jest ono jednak bezpośrednio z nim związane ${ }^{55}$.

Okazuje się, że „coraz więcej czasu pochłaniają codzienne obowiązki, a uwaga coraz częściej skupiana jest na refleksyjności, bilansowaniu życia, dążeniu do pozostawienia po sobie tego, co było w życiu najbardziej wartościowe. Strach przed śmiercią i niepełnosprawnością oraz przed samotnością największą rangę nadaje potrzebom psychicznym: akceptacji, afiliacji i miłości” ${ }^{56}$.

Tamże, s. 114.

54 H. Zielińska-Więczkowska, K. Kędziora-Kornatowska, T. Kornatowski, Starość jako wyzwanie, dz. cyt., s. 131.

55 Por. M. Brzezińska, Ucieczka od życia, „Wspólne Tematy” $2006 \mathrm{nr}$ 11-12, s. $55 \mathrm{n}$.

56 E. Trafiałek, Polska starość $w$ dobie przemian, dz. cyt. s. 106. 
Mówiąc o próbach samobójczych seniorów, trzeba wskazać na źródła subiektywne i obiektywne kryzysów osób starszych. Można do nich zaliczyć:

- wszechogarniające uczucie beznadziejności i bezradności;

- poczucie niezdolności do dalszego działania i jakiejkolwiek aktywności;

- poczucie utraty kontroli nad swoim życiem;

- poczucie niezdolności do dalszego niesienia ciężaru codziennego życia i wypełniania ról społecznych;

- zwiększenie zależności od innych;

- wysoki poziom lęku oraz występowanie i nasilenie się objawów somatycznych;

- możliwość wskazania wydarzenia krytycznego, które wywołało kryzys;

- nagłe i nieoczekiwane wystąpienie stanu nierównowagi;

- załamanie się dotychczasowych wzorów zachowania;

- występowanie poczucia dyskomfortu psychicznego ${ }^{57}$. Jak więc widać, „przeżywanie starości wiąże się z doświadczaniem wielu lęków i obaw. Badania nad poczuciem bezpieczeństwa wykazały, że samopoczucie społeczne osób w starszym wieku jest wyraźnie obarczone negatywnymi doświadczeniami, które potęgują lęk przed podobnymi doświadczeniami w przyszłości. Jednak najbardziej obawiają się oni niepełnosprawności, bólu i cierpienia, utraty samowystarczalności, sprawiania komuś kłopotu, uzależnienia od pomocy innych osób, spędzenia starości w domu pomocy społecznej, trudności w otrzymaniu pomocy oraz utraty równowagi psychicznej" 58 .

Samobójstwa są związane w dużej mierze z powstającą depresją starczą. Oto najczęstsze objawy takiej depresji:

57 Por. B. Szatur-Jaworska, P. Błędowski, M. Dzięgielewska, Podstawy gerontologii społecznej, Warszawa 2006, s. 67.

58 A. Kotlarska-Michalska, Starość $w$ aspekcie socjologicznym, dz. cyt., s. $155-156$. 
- brak energii życiowej: chory staje się apatyczny, stale zmęczony, rozdrażniony, mniej aktywny; nie jest w stanie wykonywać podstawowych zadań, które dotychczas nie sprawiały mu żadnych problemów;

- utrata zainteresowań: chory porzuca dawne hobby, pasje; nie znajduje już przyjemności w dotychczasowych zajęciach i rozrywkach; ma problemy ze snem: osoba cierpiąca na depresję ma problemy z zasypianiem, spłyceniem snu oraz wczesnym budzeniem się, to zaś skutkuje złym samopoczuciem, zmęczeniem i rozbiciem w środku dnia; charakterystyczne jest to, że chory gorzej się czuje rano, a lepiej wieczorem;

- lęk i niepokój: irracjonalne poczucie zagrożenia, oczekiwanie na same złe wydarzenia; często lęk jest długofalowy oraz umiejscowiony w okolicy przedsercowej;

- zaniedbywanie higieny własnej i otoczenia, w którym człowiek żyje;

- brak apetytu i - co za tym idzie - spadek masy ciała;

- brak koncentracji: osoba nie może skupić się na niczym; ma stale gonitwę myśli; nie jest w stanie skoncentrować się na pracy, nauce;

- poczucie winy oraz poczucie niskiej wartości - chory bardzo surowo ocenia siebie oraz swoje osiągnięcia; uważa raczej, że nic sobą nie reprezentuje, a złe wydarzenia, jakie spotkają go w życiu, to kwestia kary;

- może także pojawić się większe spożycie alkoholu lub innych używek ${ }^{59}$.

W tym miejscu warto pokusić się o podanie konkretnych przyczyn dotyczących samych samobójstw seniorów. Wśród najczęstszych czynników ryzyka próby samobójczej wśród osób starszych wymienia się:

- przechodzenie choroby mentalnej, np. depresji;

59 Por. E. Wołodźko, Depresja u ludzi starszych, zdrowie.gazeta.pl/ Zdrowie/1,105806,10491042,Depresja_u_ludzi_starszych.html (15.02.2014). 
- uzależnienie od alkoholu;

- doświadczanie przewlekłej choroby somatycznej;

- nagłą utratę dotychczasowej pozycji społecznej lub rodzinnej;

- utratę bezpieczeństwa finansowego;

- poczucie izolacji;

- utratę życiowego partnera ${ }^{60}$.

Problem kondycji psychoduchowej seniorów jest niewątpliwie wyzwaniem współczesnych czasów. Stąd też Jan Paweł II apelował do nich w następujący sposób: „Drodzy ludzie starzy, trapieni przez kłopoty ze zdrowiem lub problemy innego rodzaju, jestem całym sercem z wami. Kiedy Bóg przyzwala, abyśmy cierpieli z powodu choroby, samotności lub z innych przyczyn związanych z podeszłym wiekiem, zawsze obdarza nas też łaską i mocą, byśmy z jeszcze większą miłością włączali się w ofiarę Jego Syna i głębiej uczestniczyli w realizacji Jego zbawczego zamysłu. Możemy być pewni, że On jest Ojcem bogatym w miłość i miłosierdzie!"61

\section{Problemy w pełnieniu ról (rodzice, dziadkowie)}

Nie ma żadnych wątpliwości, że „aktywność rodzinna osób w starszym wieku była przedmiotem wielu badań socjologicznych. Wykazały one, że osoby w starszym wieku bardzo chętnie podejmują się czynnej roli dziadka i babci. Jest to rola ogromnie satysfakcjonująca. Niezmiernie rzadko określana jest jako obciążająca fizycznie i psychicznie. Wręcz przeciwnie, staje się ona źródłem satysfakcji i zadowolenia. W globalnej ocenie życia dokonywanej przez osoby pełniące rolę dziadka czy babci właśnie te role stanowią

60 Por. J. Papiernik, Samobójstwa osób starszych, www.zycie.senior. pl/147,0,Samobojstwa-osob-starszych,8425.html (12.02.2014).

61 Jan Paweł II, List do moich Braci i Sióstr - ludzi w podeszłym wieku, dz. cyt., 13. 
podstawę oceny. Można również zaryzykować stwierdzenie, że dzięki wnukom życie człowieka w starszym wieku nabiera właściwych barw. $Z$ jednej strony posiadanie wnuków zmusza do aktywności ruchowej i umysłowej, a z drugiej - sprzyja zadowoleniu z kontynuacji linii biologicznej"62.

Trzeba jednak liczyć się z badaniami, które wskazują na fakt, iż współczesny senior, szczególnie w Polsce, coraz częściej cierpi na depresję. Okazuje się, że „im ktoś starszy, w tym gorszej jest kondycji psychicznej, zwłaszcza jeśli chodzi o symptomy nieprzystosowania (depresji). Co więcej, w przeciwieństwie do społeczeństw zachodnich (USA, Kanada) w Polsce zależność (kilkakrotnie niż tam silniejsza) między wiekiem i depresją jest nie negatywna, lecz pozytywna. W Stanach Zjednoczonych to ludzie młodsi częściej cierpią na depresję niż starsi, w Polsce zaś odwrotnie: niemal z każdym rokiem życia zwiększa się nasilenie objawów depresji psychicznej"63.

Do problemów, z jakimi boryka się senior, zalicza się kwestię akomodacji do pełnienia nowych ról społecznych bądź zaprzestania niektórych z nich. „Osoby dotychczas aktywne zawodowo stają się zawodowo bierne, producenci - dawcy przemieniają się w biorących. W rodzinie - do niedawna żywiciele, opiekunowie i wychowawcy swych dzieci, obdarzeni autorytetem - sami zaczynają potrzebować pomocy i opieki, tracąc wiele na znaczeniu. Następuje więc swoiste odwrócenie ról”' ${ }^{4}$.

Nie każdy z seniorów umie sprostać tej sytuacji. Co więcej, nowa rzeczywistość może przysparzać wiele problemów zarówno dla osób starszych i ich rodzin, jak i dla

${ }^{62}$ A. Kotlarska-Michalska, Starość $w$ aspekcie socjologicznym, dz. cyt., s. 153.

63 Diagnoza społeczna 2011. Warunki życia Polaków. Raport Rady Monitoringu Społecznego, red. J. Czapiński, T. Panek, Warszawa 2011, s. 168.

64 J. Piotrowski, Miejsce człowieka starego $w$ rodzinie $i$ społeczeństwie, Warszawa 1973, s. 25. 
całego społeczeństwa. Trzeba też pamiętać, iż „nie można sobie wyobrazić, by ktoś znalazł zaspokojenie potrzeby sensu życia, uciekając od wysiłku i to od wysiłku zorganizowanego, ale powinien to być wysiłek spontaniczny, niewymuszony, sprawiający jednostce przyjemność" 65 .

W tym kontekście można pokusić się o wyodrębnienie kilku obszarów problemów w pełnieniu ról społecznych przez seniorów. Stanowią one wyzwanie dla państwa, społeczeństwa, ale także dla poszczególnych rodzin. Oto owe obszary.

\section{Obszary problemów w pełnieniu ról społecznych przez seniorów:}

1. Nadmierne wtrącanie się $\mathrm{w}$ małżeńskie sprawy własnych dzieci.

2. Przesadne ingerowanie $\mathrm{w}$ proces wychowania wnuków.

3. Nieumiejętność radzenia sobie z wdowieństwem w kontekście relacji z rodziną.

4. Ucieczka przed regularną pomocą swoim dzieciom (np. opieka nad wnukami).

5. Nachalność w proponowaniu pomocy swoim dzieciom.

6. Nieumiejętność radzenia sobie z pełnieniem roli teściów.

7. Zamykanie się na życie towarzyskie.

8. Reorientacja w pełnieniu roli małżonka (np. w dziedzinie seksualnej).

9. Histeryczna koncentracja na sobie w celu wywołania zainteresowania i angażowania innych do okazywania troski i poświęcania czasu.

65 K. Obuchowski, Człowiek, dążenia, sens. Myśli wybrane, Bydgoszcz 2001, s. 46. 
10. Mentorskie i apodyktyczne podejście do młodych.

11. Problemy sąsiedzkie w postaci zachowań pretensjonalnych i roszczeniowych.

12. Starcza tendencja do gromadzenia dóbr oraz skąpstwo.

13. Zazdrość wobec innych ludzi powodująca zakłócenia w budowaniu dobrych relacji.

14. Złośliwość lub demencja starcza prowadzące do zakłóceń komunikacyjnych.

15. Postawa wycofania się z pełnienia jakiejkolwiek roli społecznej.

Źródło: opracowanie własne.

W pełnieniu ról społecznych przez seniorów istotną kwestią jest styl bycia dziadkiem lub babcią. Wydaje się, że wiele zależy do tego, jaki styl wybiorą ludzie starsi. Oto dwie typologie, które pokazują ową problematykę.

Pierwsza z nich to typologia dziadków zaprezentowana przez Nauma Chmielnickiego:

- formaliści (ograniczają się w kontaktach z wnukami do koniecznych spotkań, mając świadomość decydującej roli wychowawczej rodziców);

- zastępcy (pełnią rolę rodziców wobec wnuków);

- „krynica mądrości rodzinnej” (przekazują wspomnienia o tradycjach rodzinnych);

- rozrywkowi (utrzymują stosunki z wnukami oparte na zabawie i wzajemnej satysfakcji);

- św. Mikołaje (rzadko kontaktują się z wnukami, ale obdarzają je prezentami) ${ }^{66}$.

Druga typologia, tym razem dotycząca roli babci, została przed laty zaprezentowana przez Irenę Rybczyńską:

66 Por. N. Chmielnicki, Dziadkowie, babcie, wnuki, „Problemy Rodziny” 1978 nr 1, s. 29-35. 
- babcia matkująca (nie wie, jak być babcią, ale wie, jak być matką i wchodzi w tę rolę);

- babcia obojętna (nie odczuwa potrzeby bycia z wnukami);

- babcia wyemancypowana (kocha swoje wnuki, ale nie ma dla nich czasu, bo przeżywa drugą młodość);

- babcia w pretensjach (ukrywa fakt, że jest babcią, nie pozwala się tak nazywać, chce zatrzymać czas);

- babcia normalna (wnuki obdarza czułością, ale nie wchodzi w kompetencje rodziców);

- babcia dyspozycyjna (pojawia się wtedy, kiedy jest potrzebna);

- babcia wszechmatka (obdarza wnuki wielką miłością, tak jak swoje dzieci);

- babcia męczennica (opiekuje się wnukami, ale podkreśla swoje wyrzeczenia);

- babcia dyktator (decyduje o wszystkim, narzucając swoją wolę) $)^{67}$.

Jakże na koniec refleksji na temat pełnienia przez seniorów ról społecznych nie przytoczyć słów Benedykta XVI, który w 2008 roku mówił do przedstawicieli Papieskiej Rady ds. Rodziny: „Wasze zgromadzenie plenarne rozważało zagadnienie obecności dziadków w rodzinie, w Kościele i w społeczeństwie w szerokiej perspektywie, uwzględniającej przeszłość, teraźniejszość i przyszłość. Przeanalizujmy pokrótce te trzy okresy. W przeszłości dziadkowie odgrywali ważną rolę w życiu i rozwoju rodziny. Także w podeszłym wieku mieli wciąż udział w życiu swoich dzieci, wnuków, a być może i prawnuków, dając na co dzień żywe świadectwo troskliwości, poświęcenia i bezwarunkowego oddania. Byli świadkami osobistej i wspólnotowej historii, która żyła w ich wspomnieniach i mądrości. Dziś rozwój ekonomiczny i społeczny przyniósł poważne zmiany w życiu rodzin. Ludzie starsi, a wśród

67 Por. I. Rybczyńska, Jak być (kochaną) babcią, Warszawa 1976, s. $136-146$. 
nich wielu dziadków, znaleźli się w czymś na kształt «strefy parkingowej»: niektórzy widzą, że są ciężarem dla rodziny, i wolą żyć sami lub w domach spokojnej starości, ze wszystkimi konsekwencjami, jakie te decyzje za sobą pociągają"68.

\section{Aktywizacja osób starszych}

Benedykt XVI w 2010 roku mówił: „Na samym początku mojego pontyfikatu powiedziałem: «Każdy z nas jest chciany, każdy jest kochany, każdy jest niezbędny» (homilia podczas Mszy św. z okazji inauguracji pontyfikatu, 24 kwietnia 2005 r.). Życie jest darem unikalnym, w każdej jego fazie, od poczęcia do naturalnej śmierci, i tylko do Boga należy dawanie go i odbieranie. W starości człowiek może cieszyć się dobrym zdrowiem, jednak chrześcijanie nie powinni lękać się dzielenia cierpień Chrystusa, jeśli z woli Boga przychodzi im zmierzyć się z chorobą. W ostatnich latach swego życia mój poprzednik, śp. papież Jan PawełII, cierpiał na oczach wszystkich. Dla nas wszystkich było jasne, że jednoczył swoje cierpienia z cierpieniami naszego Zbawiciela. Pogoda i cierpliwość, z którymi przeżywał swoje ostatnie dni, były znaczącym i poruszającym przykładem dla tych z nas, którzy muszą dźwigać brzemię wieku" ${ }^{69}$.

Przykład znoszenia cierpienia przez Jana Pawła II jest dowodem na to, że można z godnością dostrzec głębszą istotę choroby, a w konsekwencji odkryć tajemnicę krzyża. Niestety, współczesny człowiek może zderzyć się ze starością niejako na trzech płaszczyznach. Proces starzenia się może przebiegać w trzech rożnych kierunkach:

- „starzenie się zwyczajne (usual ageing) - odczuwalne są straty oraz deficyty, ale bez patologii;

68 Benedykt XVI, Do uczestników XVIII Zgromadzenia Plenarnego Papieskiej Rady ds. Rodziny (15.04.2008), dz. cyt., s. 28.

69 Benedykt XVI, Wizyta w Domu św. Piotra (Londyn, 18.09.2010), dz. cyt., s. 35. 
- starzenie się pomyślne (successful ageing) - gdy predykatory starości odgrywają neutralną rolę lub pozytywną - czyli zwalniają proces starzenia się;

- starzenie się patologiczne (impaired ageing) - szybko postępuje upośledzenie wielu funkcji życiowych organizmu oraz występuje tzw. polipatologia (współwystępowanie licznych jednostek chorobowych)"70.

Oczywiście, najbardziej pożądanym sposobem starzenia się jest successful ageing. Zadowolenie z własnej przeszłości i obecnego życia jest najczęściej proponowaną definicją pomyślnego starzenia się, a także najczęściej badaną ${ }^{71}$. Podstawowe warunki pomyślnego starzenia się definiowane są następująco:

- utrzymanie zadowalającego stanu zdrowia (niezależności funkcjonalnej);

- utrzymanie niezależności finansowej i mieszkaniowej;

- utrzymywanie więzi rodzinnych i społecznych;

- możliwość kształcenia się i samorealizacji.

Nie da się ukryć, że istotnym elementem omawianego starzenia się jest aktywność - zarówno ta fizyczna, jak i psychiczna. Jak wiadomo, „aktywność jest zdolnością do intensywnego działania; jest to energia, która stwarza szansę na kontaktowanie i porozumiewanie się z innymi ludźmi, co ma szczególne znaczenie w wieku starszym. Aktywność umożliwia zaspokojenie potrzeb biopsychospołecznych, daje poczucie satysfakcji. Jest warunkiem odgrywania ról społecznych, funkcjonowania w grupie, w społeczeństwie"72.

70 T. B. Kulik, M. Janiszewska, E. Piróg i in., Sytuacja zdrowotna osób starszych w Polsce i innych krajach europejskich, „Medycyna Ogólna i Nauki o Zdrowiu" 2011 nr 2, s. 92.

${ }^{71}$ Por. R. J. Havighurst, Successful aging, [w:] Processes of aging, ed. R. H. Williams, C. Tibbits, W. Donahue, New York 1963, s. 299-320.

72 M. Kaczmarczyk, E. Trafiałek, Aktywizacja osób starszych jako szansa na pomyślne starzenie się, "Gerontologia Polska” 15 (2007) nr 4, s. 116. 
We współczesnym świecie osoby starsze napotykają lub same stwarzają wiele przeszkód dla owej aktywności. I tak można podać przynajmniej kilka barier w uczeniu się:

- tendencja do uczenia się konserwatywnego („ludzie dorośli najchętniej uczą się tego, co już wiedzą");

- bezkrytyczność względem treści przyswojonych we wczesnej fazie życia (dorośli uczą się na schematach znaczeniowych, które powstały w dzieciństwie, a zatem w fazie, kiedy człowiek jest mocno zależny od otoczenia i cechuje go niska zdolność do krytycy$\mathrm{zmu}$ );

- dysfunkcyjność schematów względem szybko zmieniającej się rzeczywistości (wiąże się z tempem zmian we współczesnych społeczeństwach - a schematy z natury są strukturami sztywnymi i nie poddają się tak łatwo modyfikacji);

- brak pewności siebie (aktywność i zaangażowanie się w proces edukacyjny może znacząco hamować obawa przed porażką, niepowodzeniem, ośmieszeniem na forum grupy);

- duma (często towarzyszy temu ukryty niepokój, lęk o utratę pozycji zawodowej i poczucie zmniejszającej się przydatności zawodowej);

- opór, brak motywacji (uczenie się ludzi dorosłych często jest mieszanką konieczności i możliwości, zdarza się też tak, że ludzie uczą się, ale nie podjęli się tego zadania z własnej woli);

- zaniżone lub zawyżone wyobrażenie o sobie (często dorośli nie chcą podejmować się pewnych zadań edukacyjnych, bo nie mają pełnego i właściwego obrazu swoich możliwości i wiedzy);

- presja (barierą w uczeniu się może być nadmierna presja odczuwana przez dorosłego w domu; naukę utrudniać może też brak czasu, pieniędzy, nadmiar obowiązków, stan zdrowia; 
- nastawienie na uczenie się (wcześniejsze doświadczenia edukacyjne, jeśli były one trudne, nieprzyjemne, to zaangażowanie w aktywne uczestnictwo nie będzie dla jednostki łatwe $)^{73}$.

Współczesna cywilizacja, wbrew pozorom, nie pozwala na zbytnią aktywność seniorów. Można w tym zakresie wyróżnić kilka czynników ograniczających aktywność zarówno fizyczną, psychiczną, jak i duchową osób starszych.

Rys. 4. Demotywatory aktywności seniorów
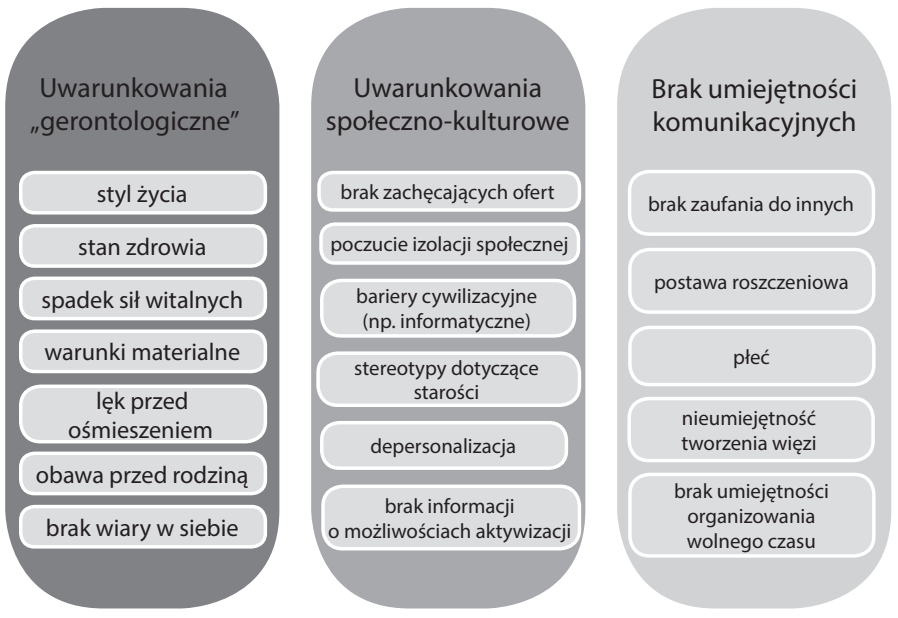

Źródło: opracowanie własne.

Jakże w tym miejscu nie przytoczyć słów Jana Pawła II skierowanych do seniorów: „Wszyscy znamy ludzi starych, którzy mogą być wymownym przykładem zdumiewającej młodości i żywotności ducha. Tych, którzy

73 Por. A. Nizińska, Uczenie się $w$ dojrzałej i późnej dorostości, [w:] Silver team, czyli potęga doświadczenia. Poradnik trenera osób starszych, Wrocław 2013, s. 16-17. 
się z nimi stykają, potrafią słowem pobudzać do działania, dodając otuchy własnym przykładem. Oby społeczeństwo umiało $\mathrm{w}$ pełni docenić ludzi starych, którzy w pewnych częściach świata - mam na myśli zwłaszcza Afrykę - słusznie są darzeni szacunkiem jako «żywe biblioteki» mądrości, strażnicy bezcennego dziedzictwa ludzkiego i duchowego. Choć to prawda, iż w wymiarze fizycznym zazwyczaj potrzebują pomocy, prawdą jest też, że nawet w podeszłym wieku mogą być oparciem dla młodych, którzy stawiają pierwsze kroki w życiu i szukają swojej drogi"74.

\section{Problemy natury religijnej}

Mówiąc o problemach religijnych seniorów, trzeba sobie uświadomić, że „w ostatnim okresie życia następuje dalsza polaryzacja religijności. U dużej grupy osób starszych dostrzega się swoistą mądrość życiową, która wyraża się wyrozumiałością, życzliwością, pragnieniem dzielenia się swoimi doświadczeniami. U innych raczej małostkowość, łatwość "gorszenia się», a nawet agresywność"75. Trzeba też pamiętać, że „starość w świetle Bożych zamysłów jest uwieńczeniem całego procesu duchowego wzrastania, mającego na celu osiągnięcie chrześcijańskiej doskonałości i świętości życia. Jest to zatem czas stosowny do rozwijania intensywniejszej modlitwy indywidualnej i wspólnotowej, np. w grupach religijnych, zespołach apostolskich lub ruchach odnowy charyzmatycznej, a także czas stosowny do częstej i pogłębionej lektury Pisma świętego. Wielu ludzi starszych praktykuje regularną spowiedź, głównie

74 Jan Paweł II, List do moich Braci i Sióstr - ludzi w podeszłym wieku, dz. cyt., 12.

75 E. Osewska, Rozwój religijności człowieka ze szczególnym uwzględnieniem rozwoju modlitwy, [w:] Dzisiejszy katecheta. Stan aktualny $i$ wyzwania, red. J. Stala, Kraków 2002, s. 323. 
w pierwsze piątki miesiąca, a także codziennie lub prawie codziennie uczestniczy we Mszy św., co jest godne uznania i polecenia innym"76.

Według Marii Straś-Romanowskiej istnieje kilka istotnych cech charakteryzujących duchowość seniora. Oto te najważniejsze:

- wyciszenie umysłu i wsłuchanie się w siebie, czemu sprzyja wycofanie się podmiotu z aktywnego życia (zawodowego, rodzinnego, towarzyskiego) bez poczucia żalu, a z poczuciem uwolnienia się, niezależności;

- spokojne tempo życia, prosty i stabilny jego tryb, który swoją monotonią nadaje rytualny charakter, określany niekiedy z tego powodu mianem klasztornego;

- wyciszenie umysłu oraz refleksję ułatwia też ogólny spadek energii życiowej człowieka starzejącego się, osłabienie popędów i potrzeb witalnych ${ }^{77}$;

- tzw. introwertyzacja, która sprzyja twórczemu przepracowywaniu doświadczenia, autokonfrontacji, „rozliczaniu się" z sobą, co prowadzi - po licznych niekiedy trudach i bólu - do wewnętrznego spokoju, harmonii i lekkości ducha;

- koncentrowanie się na swoim wnętrzu, wspomnieniach, rozterkach, przeżyciach, które samo przez się nie gwarantuje jednak rozwoju - niezbędna jest do tego celu wola, autodeterminacja, połączona z gotowością do znoszenia przykrości, bólu psychicznego, a nawet cierpienia $^{78}$;

- „Całościowe, syntetyczne i intuicyjne ujmowanie doświadczeń (związane z funkcjami prawej półkuli mó$\mathrm{zgu}$ ) ułatwia $\mathrm{z}$ jednej strony wnikanie $\mathrm{w}$ istotę rzeczy

76 W. Przygoda, Formacja apostolska ludzi w podeszłym wieku, „Perspectiva" 8 (2009) nr 1, s. 177.

77 Por. M. Straś-Romanowska, Starzenie się jako kontekst rozwoju duchowego człowieka, [w:] Ludzie starsi w trzecim tysiacleciu. Szanse - nadzieje - potrzeby, red. W. Wnuk, Wrocław 2002, s. 31.

78 Por. tamże, s. 32. 
i pogłębione rozumienie, $z$ drugiej zaś wykraczanie w poznaniu poza rzeczywistość widzialną, materialną - w kierunku świata transcendentnego, metafizycznego. Wartości tego świata, czyli wartości duchowe, stają się wówczas dla osoby bardziej oczywiste, pewne, bezdyskusyjne (Trigg, 1989)"79.

Inna autorka dodaje do tych cech także osiąganie przez osoby zaangażowane religijnie wglądu w sprawy ostateczne, takie jak: „ocena wartości życia, śmierć, życie wieczne, ostateczny wybór wartości religijnych. Dzięki temu nawet codzienne czynności nabierają wymiaru eschatologicznego. Religijna wiara w Boga pomaga ludziom starym powracać do stanu scalonej osobowości po przeżyciu żałoby, nieszczęścia, samotności, depresji”"80.

Cytowana powyżej Maria Straś-Romanowska podaje również bardzo konkretne czynniki rozwoju duchowego człowieka starszego. Do najważniejszych zalicza następujące:

- Zwiększona łatwość w zakresie:

- „kojarzenia faktów, ujmowania ich na rozległym tle sytuacyjnym i historycznym (tzw. myślenie kontekstualne);

- łączenia i rozumienia przeciwieństw, przezwyciężania logicznych sprzeczności i dokonywania syntez (tzw. myślenie paradoksalne lub dialektyczne);

- uwzględniania wielu różnorodnych perspektyw czy punktów odniesienia w interpretowaniu zdarzeń (tzw. myślenie relatywistyczne)" 81 ;

- „Bogactwo doświadczeń, w tym szczególnie doświadczenie przemijania, utraty różnorodnych dóbr, dewaluacji wartości materialnych, względności ocen, a także wyzbycie się złudzeń co do roli racjonalnego rozumu,

79 M. Straś-Romanowska, Starzenie się jako kontekst rozwoju..., dz. cyt., s. 33.

80 E. Osewska, Rozwój religijności człowieka..., dz. cyt., s. 324.

81 Tamże. 
możliwości kontrolowania biegu zdarzeń i pełnego kierowania własnym życiem. W następstwie tych doświadczeń rodzi się dystans do siebie i do własnego życia, pokora, wyrażająca się w postawie typu «niech będzie»" 82 .

- Nagłe losowe, a przy tym przykre zdarzenia - dla wielu osób mogą stanowić „główny bodziec stymulujący zmianę sposobu patrzenia na świat oraz własne życie" ${ }^{83}$.

- „Rozmowy, wymiana doświadczeń, poglądów, dokonywane porównania społeczne - wszystko to sprzyja dostrzeganiu różnorodnych punktów odniesienia i różnorodnych sposobów interpretacji zdarzeń, ułatwia autokonfrontację i weryfikację dotychczasowego sposobu myślenia, motywuje też do nowych działań, które dotąd znajdowały się poza obszarem zainteresowań podmiotu (np. działania wspólnotowe, charytatywne, samokształceniowe itp.)" ${ }^{84}$.

Oczywiście rozwój duchowy seniorów ma także swoje zagrożenia. Okazuje się, że „ujemne zjawiska w dziedzinie cielesnej i psychicznej mają wpływ na duchowość człowieka starszego. Pomimo zauważalnego dużego zaangażowania osób w podeszłym wieku w praktyki religijne, nie da się powiedzieć, że okres ten wolny jest od wszelkiego rodzaju zagrożeń duchowych. Szczególnym problemem jest posiadanie przez osoby starsze niewłaściwego obrazu Boga, co negatywnie wpływa na ich motywację religijną"85. Jak pisze Elżbieta Osewska, „niespójne wyniki otrzymują badacze w zakresie zachowań religijnych. Niektóre badania wskazują na wzrost praktyk religijnych ludzi starszych (uczęszczanie do kościoła, czytanie Pisma Świętego, odmawianie modlitw). Inne natomiast, tak jak badania własne

Tamże.

Tamże.

Tamże.

85 J. Skowroński, Złoty wiek życia czy zrezygnowana starość, „Kotwica” 2009 nr 5 (45), s. 15. 
Moberga, rejestrują spadek praktyk religijnych. Być może należy to przypisać gorszemu stanowi zdrowia respondentów oraz zastępczemu korzystaniu z religijnych audycji radiowych i telewizyjnych" ${ }^{86}$.

Warto w tym miejscu ukazać podstawowe problemy religijne seniorów, które mogą dodatkowo pogłębiać kryzys wieku starszego. Poniższy diagram ukazuje najważniejsze obszary owych problemów.

Rys. 5. Problemy religijne seniorów

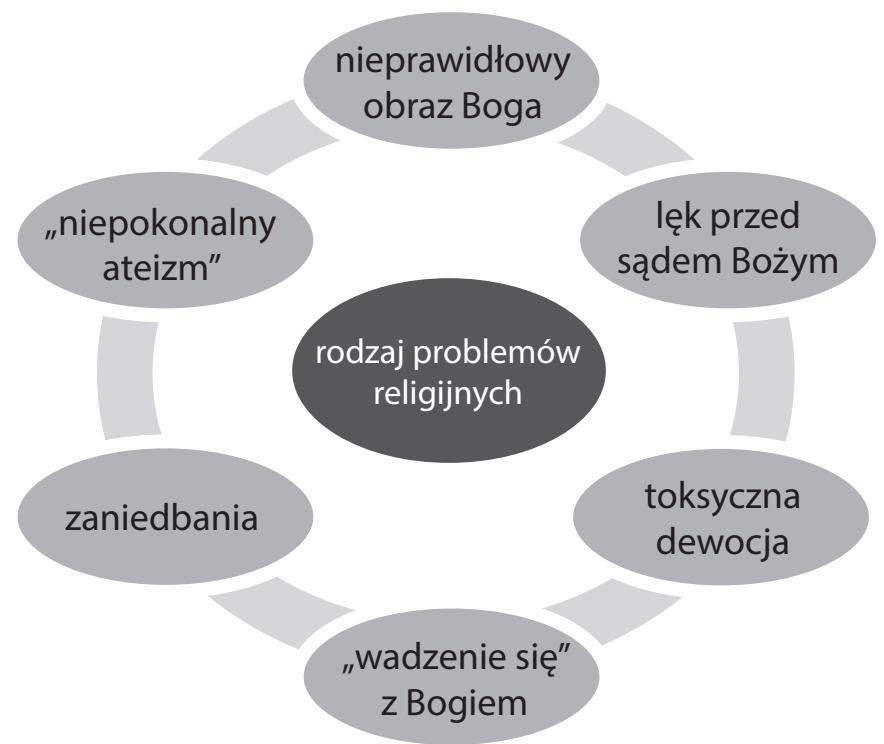

Źródło: opracowanie własne.

Pierwszym problemem religijnym seniora może być nieprawidłowy obraz Boga. Może być On odbierany jako jedynie surowy sędzia bądź to jako Stwórca, który nie jest drobiazgowy w ocenie człowieka. Powyższe skrajne podejścia

86 E. Osewska, Rozwój religijności człowieka..., dz. cyt., s. 324. 
do Boga powodują albo zbytnią odpowiedzialność za swoje czyny, albo postawę tzw. luzu moralnego. Niektórzy seniorzy wchodzą na drogę nieprzejmowania się własnymi wyborami i nie dostrzegają swoich win i grzechów.

Drugim problemem seniorów, związanym z poprzednim, jest lęk przed sądem Bożym. Jest to przesadne rozliczanie się z własnym życiem w perspektywie pogłębiającego się negatywizmu. Senior widzi siebie i całe swoje życie jako przegraną, za co odpowie przed Bogiem. Znika w jego refleksji kategoria Boga Miłosiernego. Stąd też przy spowiedziach pojawia się lęk, a dodatkowo zwiększa się częstotliwość przystępowania do sakramentu pokuty.

Kolejną trudnością związaną z religijnością osób starszych jest ich dewocja, wpływająca negatywnie nie tylko na samych seniorów, ale i na ich otoczenie. Toksyczność owej dewocji polega na mnożeniu ilości modlitw, braku troski o jakość spotkań z Bogiem, jak również nawracaniu innych „na siłę”. W konsekwencji mamy do czynienia z przerostem formy nad treścią. Choć trzeba pamiętać, że „niektórzy ludzie starsi starają się dzielić swoje przekonania i praktyki religijne z najmłodszym pokoleniem, stąd chętnie spotykają się z wnukami, rozmawiają z nimi o swoich doświadczeniach religijnych oraz wprowadzają w praktyki np.: uczą podstawowych znaków i modlitw, przypominają o modlitwie w intencji rodziny, zachęcają do udziału we Mszy św., opowiadają historie z życia świętych" ${ }^{87}$.

Następną kwestią związaną z nieprawidłowym przeżywaniem własnej religijności przez seniorów jest tzw. wadzenie się z Bogiem. Jak wiadomo, osoby starsze dokonują bilansu życiowego. Zdarza się nieraz, że pojawiają się do Boga pretensje za brak błogosławieństwa czy niewysłuchanie modlitw. Niektórzy seniorzy próbują także „wymusić” na Bogu pewne ingerencje poprzez „zawieranie po-

87 Tamże, s. 325. 
rozumień” (np. „Pójdę do spowiedzi, jeśli Bóg wysłucha mojej prośby").

Omawiając religijne problemy seniorów, nie można pominąć także ich zaniedbań. Są one związane z zarzuceniem praktyk religijnych pod byle jakim pretekstem. Najczęściej występujące usprawiedliwienia to: brak siły do regularnego życia sakramentalnego, „nie ta głowa” (rozproszenia na modlitwie), niechęć do zmiany stylu życia, brak motywacji do pojednania np. z rodziną (w związku z tym dystansowanie się do Boga) itp.

Ostatnim i wcale nie tak rzadko spotykanym problemem natury religijnej w procesie starzenia się jest „niepokonalny ateizm”. Polega on na braku umiejętności przezwyciężenia niechęci do religii, Kościoła, księży. Jest to swoista ucieczka przed religijnością. Stanowi ona trudność w podjęciu regularnego życia sakramentalnego. Może się też wiązać z lękiem przed powrotem do Kościoła (np. spowiedź po wielu latach).

Dobrą pointą powyższych refleksji mogą być słowa Jana Pawła II, który zawsze postrzegał ludzi starych jako dar dla Kościoła. Mówił do nich: „Drodzy bracia i siostry! Kościół patrzy na was z wielkim szacunkiem i zaufaniem. Kościół was potrzebuje! Ale potrzebuje was także społeczeństwo! Tak powiedziałem miesiąc temu do młodych i tak samo mówię dzisiaj do was - do nas - ludzi starszych. Kościół nas potrzebuje! Ale potrzebuje nas także społeczeństwo! Starajcie się wielkodusznie wykorzystywać czas, który macie do dyspozycji, oraz talenty udzielone wam przez Boga, gotowi służyć innym pomocą i wsparciem. Włączajcie się w głoszenie Ewangelii jako katechiści, animatorzy liturgii, świadkowie życia chrześcijańskiego. Poświęcajcie czas i energię modlitwie, czytaniu Słowa Bożego i rozważaniu go" ${ }^{\prime 8}$. Seniorzy są i pozostaną mądro-

88 Jan Paweł II, Jubileusz ludzi starszych (17.09.2000), „L'Osservatore Romano" 21 (2000) nr 11-12, s. 33. 
ścią narodów, i potrzebują wsparcia społecznego, aby mogli spełniać swoją rolę i pomagać społeczeństwu w trosce o każdego obywatela.

\section{Perspektywy}

Jak widać, współczesna cywilizacja musi zetknąć się $\mathrm{z}$ wieloma problemami związanymi z procesem starzenia się społeczeństw. Warto na koniec podać kilka kierunków rozwiązania tych problemów (zob. rys. 6).

\section{Afirmacja edukacji seniorów}

Niewątpliwie inicjatywy edukacyjne są niezwykle skutecznym sposobem wspierania osób starszych. Okazuje się, że „ludzie, zwłaszcza starzy, niejednokrotnie stają się bezradni wobec nowych wyzwań codzienności. Doświadczając wszechprzenikliwego lęku, zmuszani są do wyboru i zmiany swej tożsamości [...]. Uczenie się całożyciowe, a więc właśnie i w okresie starości, staje się zatem jedyną, nieprzecenioną szansą dla kreowania własnych (auto)biografii, poszukiwania i wybierania różnych źródeł tożsamości. [...] Edukacyjny styl życia staje się koniecznością człowieka i to koniecznością egzystencjalną"89. Stąd też istnieje ogromna potrzeba rozwijania wszelkich inicjatyw edukacyjnych skierowanych do seniorów. Należą do nich: kształcenie systematyczne (formalne, pozaformalne), kształcenie incyndentalne, nieformalne oraz samokształcenie ${ }^{90}$. Istnieje potrzeba wspierania, także finansowego, uniwersytetów trzeciego wieku. Oto kilka sugestii w tej kwestii:

89 A. Stopińska-Pająk, „Szkoła starości” - być, aby się uczyć, „Chowanna" 52 (2009) t. 2 (33), s. 15-16.

90 Por. Z. Szarota, Seniorzy w przestrzeni kulturalno-edukacyjnej społeczeństwa wiedzy, „Chowanna” 52 (2009) t. 2 (33), s. 77-96. 
Rys. 6. Przestrzenie wspierania seniorów

$$
\text { afirmacja edukacji seniorów }
$$

\section{troska o kompetencje kadr gerontologicznych}

zmiana stylu życia osób starszych

inkluzja społeczna seniorów

destereotypizacja starości

wychowanie do starości

przyjazne ustawodawstwo

rozwój placówek wspierających seniorów

Źródło: opracowanie własne.

- dofinansowanie państwowe dla edukacji w późnym wieku;

- dostosowanie do potrzeb seniorów narzędzi i oferowanie specjalnego pakietu usług;

- stymulowanie aktywności seniorów poprzez zachęcanie ich do edukacji; 
- docieranie do rodzin seniorów w celu uzyskania poparcia dla motywowania ich do aktywności edukacyjnej;

- włączanie seniorów do korzystania z cywilizacyjnych zdobyczy informatycznych (edukacja e-learning);

- opracowywanie metodologii tworzenia kursów e-learningowych dla osób starszych;

- wspieranie inicjatyw przygotowujących do efektywnego posługiwania się technologią informacyjną;

- wspieranie edukacji żywieniowej oraz afirmacja prozdrowotnego stylu życia.

\section{Troska o kompetencje kadr gerontologicznych}

Nie ma także wątpliwości, że pomoc seniorom powinna zakładać kształcenie coraz bardziej kompetentnych kadr gerontologicznych. Jak pisze Zofia Szarota, „nadanie ścisłego znaczenia pojęciu kadry gerontologiczne jest istotne przy doborze treści kształcenia i wyborze określonych form organizacyjnych dokształcania i doskonalenia zawodowego" ${ }^{1}$. W dobie procesu coraz szybszego starzenia się społeczeństw europejskich, w tym także polskiej, w sferze gerontologii poniższe postulaty są bardzo naglące. Należy zatem „w pilnym trybie:

- wprowadzić przedmiot „geriatria” do obligatoryjnego programu kształcenia studentów medycyny na kierunkach lekarskich wszystkich uczelni medycznych na bazie klinik geriatrycznych;

- wprowadzić obowiązkowe kształcenie podyplomowe lekarzy rodzinnych z zakresu geriatrii;

- zwiększyć liczbę miejsc specjalizacyjnych z geriatrii na bazie klinik i oddziałów geriatrycznych;

- inwestować w rozwój jednostek geriatrycznych wraz $\mathrm{z}$ zapewnieniem ich finansowania na podstawie real-

91 Z. Szarota, Gerontologia społeczna i oświatowa, Kraków 2004, s. 20. 
nych kosztów, a poprzez to poprawić dostępność i jakość opieki geriatrycznej nad osobami starszymi"92. Aby tak się stało, trzeba bardziej zatroszczyć się o wymienione powyżej kadry gerontologiczne. Zofia Szarota proponuje następującą typologię owych kadr.

Tab. 1. Kadry gerontologiczne - propozycja typologii

\begin{tabular}{|l|l|}
\hline \multicolumn{1}{|c|}{$\begin{array}{c}\text { Osoby oddziaływania } \\
\text { „bezpośredniego" }\end{array}$} & $\begin{array}{c}\text { Osoby oddziaływania } \\
\text { „pośredniego" }\end{array}$ \\
\hline Pracownicy pomocy & - Nauczyciele i wykładowcy \\
społecznej zatrudnieni & akademiccy, realizujący tre- \\
w ośrodkach przeznaczo- & ści gerontologiczne związa- \\
nych dla omawianej grupy & ne z pedagogiką, metodyką \\
wiekowej (pracownicy so- & zajęć z osobami starszymi, \\
cjalni, kulturalno-oświa- & psychologią drogi życiowej, \\
towi, terapeuci, rehabili- & geronto-psychologią, psy- \\
tanci, opiekunowie, średni & chologią społeczną i wycho- \\
personel medyczny). & wawczą, socjologią, socjolo- \\
Pracownicy środowiskowej & gią medycyny, demografią, \\
pomocy i opieki społecz- & polityką społeczną. \\
nej, którzy sprawują opiekę & Autorzy programów radio- \\
nad osobami starszymi. & wo-telewizyjnych, książek \\
Kadra instytucji senior- & i publikacji w czasopismach, \\
skich, pracownicy organi- & broszur o profilaktyce staro- \\
zacji pozarządowych. & ści, których audytorium sta- \\
Doradcy geragogiczni. & nowią osoby w zaawanso- \\
Przewodnicy wycieczek, & wanym wieku. \\
instruktorzy ruchu fi- & Pracownicy administracji \\
zycznego, instruktorzy & państwowej przygotowu- \\
amatorskiego ruchu ar- & jący i wdrażający projek- \\
tystycznego, prowadzą- & ty ochrony prawno-socjal- \\
cy działalność w stosun- & nej dotyczące najstarszych \\
ku do emerytów. & obywateli. \\
\hline
\end{tabular}

92 J. Derejczyk, B. Bień, J. Kokoszka-Paszkot, J. Szczygieł, Gerontologia i geriatria $w$ Polsce na tle Europy - czy należy inwestować w ich rozwój w naszym kraju?, „Gerontologia Polska” 16 (2008) nr 3, s. 157-158. 


\begin{tabular}{|l|l|}
\hline \multicolumn{1}{|c|}{$\begin{array}{c}\text { Osoby oddziaływania } \\
\text { „bezpośredniego" }\end{array}$} & \multicolumn{1}{c|}{$\begin{array}{c}\text { Osoby oddziaływania } \\
\text { "pośredniego" }\end{array}$} \\
\hline $\begin{array}{l}\text { Instruktorzy klubów, do- } \\
\text { mów kultury, animatorzy } \\
\text { prowadzący pracę z osoba- } \\
\text { mi starszymi. }\end{array}$ & $\begin{array}{l}\text { Pracownicy samorządów } \\
\text { terytorialnych. }\end{array}$ \\
Kierownicy i wykładow- & Członkowie lobby, sto- \\
cy uniwersytetów III wieku & społzyszeń i organizacji \\
oraz innych placówek upo- & których działalność kon- \\
wszechnieniowych. & centruje się wokół proble- \\
& matyki osób starszych. \\
\hline
\end{tabular}

Źródło: Z. Szarota, Gerontologia społeczna i oświatowa, Kraków 2004, s. 20.

Powyższe kadry powinny „ukształtować pozytywne nawyki przyczyniające się do dobrostanu psychofizycznego i tym samym ekonomicznego starości indywidualnej i społecznej”93.

\section{Zmiana stylu życia seniorów}

Sami seniorzy powinni także zadbać o siebie, a w szczególności zmieniać style życia. Trzeba pamiętać, że wiele osób starszych jest uzależnionych. „Ważne staje się zatem aktywizowanie seniorów, i to na wielu płaszczyznach życia: społecznego, religijnego czy politycznego. Wtedy bowiem poczucie własnej wartości i przydatności staje się działaniem prewencyjnym w stosunku do uzależnieńn 94 . Nie można też zapominać, że „ludzie starsi nadal dysponują wachlarzem metod, by polepszyć swój los, na przykład mogą przyjąć zdrowszy styl życia. Związek między stylem życia a samopoczuciem jest jednak bardziej złożony, niż początkowo mogło się to wydawać. Społeczno-ekonomiczna klasa, pochodzenie etniczne, wdowieństwo, relacje

\footnotetext{
93 Tamże.

94 N. Pikuła, E. Traczykowska, Etos starości w aspekcie społecznym, Kraków 2011, s. 87.
} 
rodzinne, finanse i wiele innych czynników wzajemnie na siebie oddziałuje" ${ }^{\prime 95}$.

Wydaje się, że można podać przynajmniej kilka postulatów dotyczących zmiany stylu egzystencji seniorów, co pozwoli na poprawę jakości ich życia:

- kształtowanie prozdrowotnych zachowań żywieniowych;

- konsekwentna walka z nałogami (alkohol, nikotynizm, telemania itp.);

- preferowanie stylu rodzinnego, w którym seniorzy odgrywają rozszerzoną rolę babci czy dziadka (np. pomagają dzieciom w opiece nad wnukami);

- aktywne spędzanie wolnego czasu;

- zaangażowanie w sprawy innych (np. poprzez wolontariat);

- podnoszenie własnych kompetencji poprzez zdobywanie nowych sprawności i umiejętności (np. posługiwanie się Internetem, komórką itp.);

- pozytywne, pełne sensu planowanie dni, miesięcy, a nawet lat;

- preferowanie treningu umysłowego, co poprawia ogólne funkcjonowanie seniorów;

- konsekwentne przeciwdziałanie automarginalizacji;

- ćwiczenie zachowań adaptacyjnych do zmieniającej się kondycji seniorów.

Oczywiście powyższe sugestie nie wyczerpują wszystkich działań na rzecz wspomagania seniorów. Wyznaczają jednak pewne standardy postaw społecznych zarówno samych seniorów, jak i osób spotykającymi się z nimi.

\section{Inkluzja społeczna seniorów}

Nie ma żadnych wątpliwości, że „przewidywane zmiany demograficzne wymagają podjęcia nowych zadań w po-

95 I. Stuart-Hamilton, Psychologia starzenia się, tłum. A. Błachnio, Poznań 2006, s. 163. 
lityce społecznej i gospodarczej państwa. Za najważniejszą należy uznać [...] konieczność prowadzenia polityki właczenia osób starszych do społeczeństwa. Proces ten może przebiegać prawidłowo wyłącznie przy podmiotowym traktowaniu tej grupy osób. Tylko ich świadomy wybór powinien określać, czy i w jakiej formie chcą podejmować określoną aktywność, w tym zawodową"

Aby mogło dojść do swoistej inkluzji społecznej seniorów, potrzebne są przede wszystkim poprawne kontakty międzypokoleniowe. Kontakty te muszą podlegać spełnieniu następujących warunków:

- zamierzenia osób młodych i starszych odznaczają się określoną zgodnością;

- starsi są postrzegani przez młodych jako osoby posiadające kompetencje, które pozwalają na skuteczną realizację formułowanych celów przejmowanych przez młode pokolenie;

- seniorzy są odbierani pozytywnie, zarówno pod względem merytorycznego przygotowania do życiowych zadań, jak i ewentualnego wspomagania innych w optymalizacji działań związanych z osiąganiem określonych zadań;

- relacje pomiędzy młodymi i starszymi charakteryzują się otwartością przeżyciową ${ }^{97}$.

Trzeba także podkreślić, że „zahamowanie, ograniczenie procesów marginalizacji i wykluczenia społecznego wymagałoby zmian $\mathrm{w}$ rozwoju społeczno-gospodarczym w ujęciu globalnym, a także stworzenia społeczeństwa obywatelskiego. Zasadne byłoby podjęcie działań na rzecz pobudzania aktywności jednostek, grup społecznych - w obszarze edukacji, dostępu do wysokiej jakości oświaty, do

96 G. Ciura, J. Szymańczak, Starzenie się społeczeństwa polskiego, „Infos. Zagadnienia Społeczno-Gospodarcze" 2012 nr 12, s. 4.

97 Por. J. Mańczak, Wykluczenie kulturowe - dysfunkcjonalność kulturowa ludzi starszych, [w:] Życie w starości, dz., cyt., s. 276-277. 
rynku pracy, zabezpieczenia społecznego, do ochrony zdrowia, do sfery kultury i polityki" 98 .

Nie ma wątpliwości, że istotnym fundamentem inkluzji seniorów jest ich kapitał społeczny. Chodzi o jego zidentyfikowanie, uruchomienie, a w konsekwencji wykorzystanie. Aby tak się stało, potrzeba zmiany myślenia całego społeczeństwa na temat osób starszych i ich roli społecznej.

\section{Destereotypizacja starości}

Z wielu badań socjologów i gerontologów wynika, że „ambiwalencja postaw wobec starości wskazuje na dwa niezależne heurystyczne archetypy starości, przywoływane w zależności od kontekstu sytuacyjnego. $Z$ jednej więc strony starość to mądrość i doświadczenie budzące szacunek. Z drugiej strony - cechy psychiczne i somatyczne budzą niechęć [...]. W przypadku starości uderza ogromny dystans symboliczny między dwoma biegunami tej dwoistości oraz usytuowanie tych biegunów na jednym kontinuum. Innymi słowy, sprzeczne normy szacunku do ludzi starych i lekceważenia ludzi starych mogą funkcjonować równolegle. To, który archetyp starości przywołuje się, jest wtórne wobec jego funkcjonalności (adekwatności) w danym kontekście sytuacyjnym, społecznym oraz kulturowym"99. W związku z tym warto sformułować kilka postulatów dotyczących zmiany zarówno stereotypizacji wieku starszego, jak i jego tabuizacji. Oto one:

- potrzeba zmiany sposobu ukazywania seniorów w mediach;

98 A. Nowak, Pojęcie, istota, przyczyny, mechanizmy marginalizacji $i$ wykluczenia społecznego, „Chowanna” 55 (2012) t. 1 (38), s. 30-31.

99 Ł. Łotocki, Barwy jesieni. O społeczno-kulturowym obrazie starości, „Problemy Polityki Społecznej” 2012 nr 17, s. 134. 
- uświadomienie społeczeństwu stereotypów związanych z seniorami, które mijają się z prawdą;

- preferowanie tzw. rekategoryzacji polegającej w tym przypadku na zachęcaniu ludzi, aby postrzegali starszych nie tylko jako osoby słabe, będące ciężarem, ale jako przedstawicieli szerszej grupy społecznej, niewywołującej negatywnych skojarzeń;

- zachęta do częstszych kontaktów z seniorami (takie kontakty nierzadko likwidują uprzedzenia i stereotypy);

- dostrzeganie walorów osobistych poszczególnych seniorów;

- reorientacja językowa polegająca na używaniu terminów o zabarwieniu pozytywnym - dotyczących seniorów.

Destereotypizacja starości jest niezwykle potrzebna, bowiem "dylematy ludzi starszych w sytuacji przemian to: jak stawić czoła przeżywaniu naszych czasów, czy tylko zapełnić białe plamy, analizować stosunek do przeszłości, teraźniejszości i przyszłości, czy podjąć odpowiedzialność za prawa obywatelskie, włączyć się w ruch samorządowy"100. Tylko pozytywne, przyjazne podejście do seniora może pomóc mu w rozwiązaniu jego problemów i dylematów.

\section{Wychowanie do starości}

Jak pisze Zofia Sarota, „przygotowanie do starości nie polega na rozmowach o trybie życia właściwym dla pokolenia seniorów, ale jest to konkretne organizowanie sytuacji życiowych odnoszących się do ludzi młodych i dojrzałych"101. Autorka zaproponowała pożądane czynniki procesu wychowania do starości.

\footnotetext{
100 A. Czerniawska, Drogi $i$ bezdroża andragogiki i gerontologii, Łódź 2000, s. 162.

101 Z. Szarota, Gerontologia spoteczna..., dz. cyt., s. 59-60.
} 


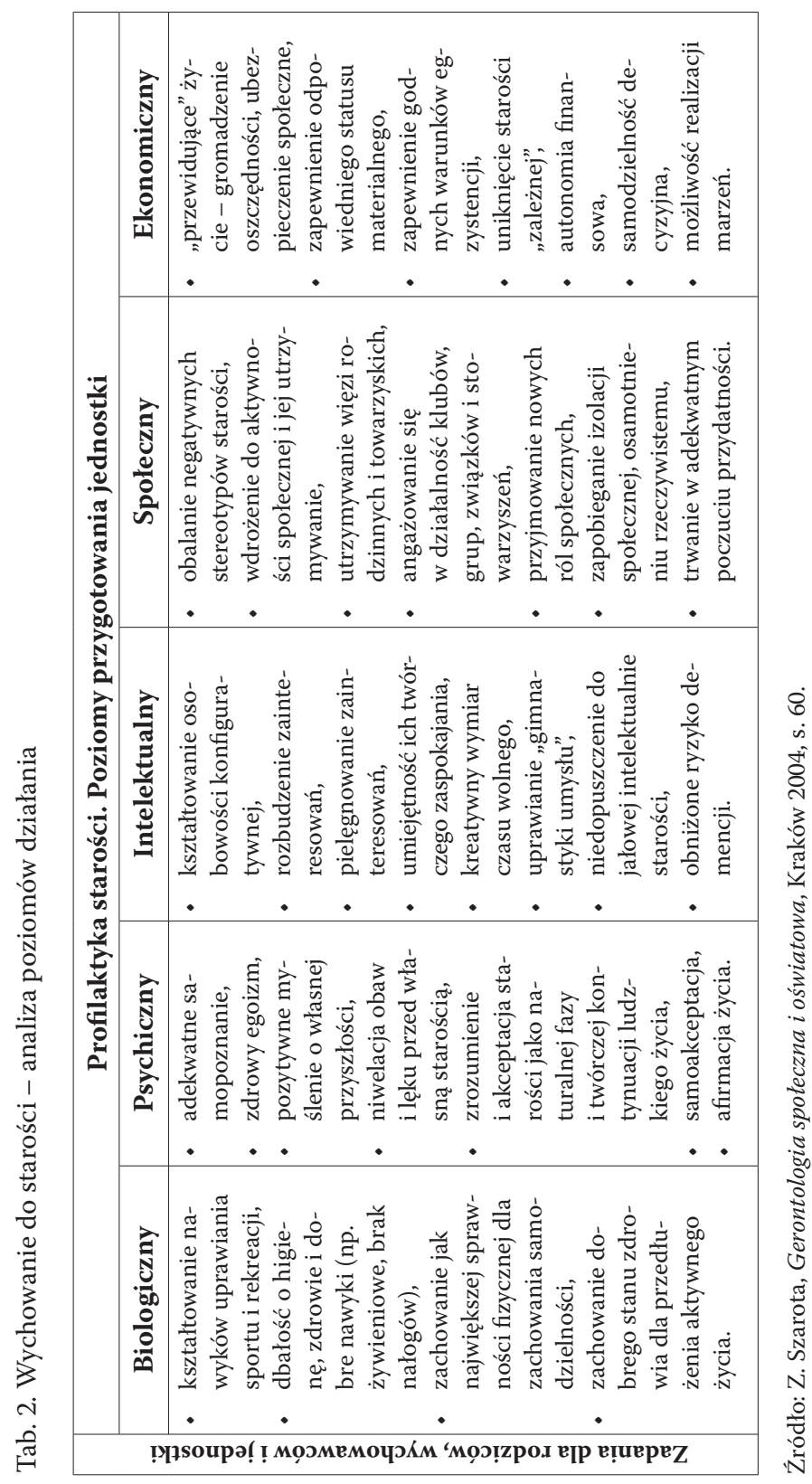


Jak widać, przygotowanie się do starości stanowi nowe wyzwanie dla społeczeństw. Chodzi więc o działania edukacyjne na rzecz przygotowania młodego pokolenia do zmierzenia się w przyszłości z zadaniami rozwojowymi starości. Wydaje się, że „prawidłowe przygotowanie do starości jest najlepszym sposobem na godzenie się ludzi z wkraczaniem w ostatnią fazę życia, dostrzeganie w starości interesującego etapu, który może być drogą do spełnienia niezrealizowanych dotąd planów. [...] Należy zatem podjąć działania mające na celu wykorzystanie zasobów społecznych, jakie stoją za seniorami - ich doświadczenia, wiedzy, wolnego czasu, zaangażowania społecznego"102.

\section{Przyjazne ustawodawstwo}

Jednym $\mathrm{z}$ istotnym elementów skutecznego wspierania seniorów jest odpowiednie ustawodawstwo państwowe. Trzeba pamiętać, że „przed polską polityką społeczną stoi wiele wyzwań. Jednym z najważniejszych jest zapewnienie poczucia sprawiedliwości międzypokoleniowej oraz społecznej spójności (social cohesion). U podstaw tego zadania leży dostosowanie polityki społecznej do rzeczywistych potrzeb seniorów. Obecny model jest dla ludzi starszych zbyt zinstytucjonalizowany, sformalizowany, a co za tym idzie - abstrakcyjny. Realizacja skutecznej „polityki starzenia się" powinna rozpocząć się na szczeblu lokalnym, na przykład od usunięcia z przestrzeni miejskiej barier architektonicznych, budowy bezpiecznych przejść dla pieszych, zapewnienia przyjaznych seniorom usług transportowych, możliwości skorzystania z osiedlowych stołówek"103.

102 I. Gołębiewska, Wspótczesna starość - czy można się do niej przygotować? „Cywilizacja” 2012 nr 42, s. 36.

103 K. Zapędowska, Polityka społeczna wobec osób starszych - utopia czy konieczność, http://liberte.pl/polityka-spoleczna-wobec-osob-starszych-utopia-czy-koniecznosc (20.02.2014). 
Z nadzieją trzeba przyjąć inicjatywę Rady Ministrów z grudnia 2013 roku, dotyczącą kompleksowego programu wspierania osób starszych. W lutym 2014 roku w „Monitorze Polskim" została opublikowana uchwała Rady Ministrów w sprawie przyjęcia dokumentu Założenia Dtugofalowej Polityki Senioralnej w Polsce na lata 2014-2020104. Jak sami autorzy projektu wyjaśniają, „polityka senioralna jest to ogół celowych działań organów administracji publicznej wszystkich szczebli oraz innych organizacji i instytucji, które realizują zadania i inicjatywy kształtujące warunki godnego i zdrowego starzenia się"105. Autorzy przyjętych przez rząd założeń są przekonani, że „celem polityki senioralnej w Polsce będzie wspieranie i zapewnienie możliwości aktywnego starzenia się w zdrowiu oraz możliwości prowadzenia $\mathrm{w}$ dalszym ciągu samodzielnego, niezależnego i satysfakcjonującego życia, nawet przy pewnych ograniczeniach funkcjonalnych"106.

Okazuje się, że główne zidentyfikowane wyzwania dla polityki senioralnej, wokół których wypracowano kierunki interwencji, to:

- zwiększający się udział osób starszych w populacji i przygotowanie się na wiele społecznych i ekonomicznych konsekwencji tego zjawiska,

- wydłużenie okresu aktywności zawodowej,

- włączenie potencjału osób starszych w obszar aktywności społecznej i obywatelskiej ${ }^{107}$.

Cieszy fakt, że w zaprezentowanym projekcie zostały zawarte konkretne propozycje wsparcia seniorów. Co więcej, istnieje szansa, że owe założenia kompleksowej polityki

104 Założenia Dtugofalowej Polityki Senioralnej w Polsce na lata 20142020. Uchwała Rady Ministrów Rzeczypospolitej Polskiej z dnia 24 grudnia 2013, „Monitor Polski. Dziennik Urzędowy Rzeczypospolitej Polski" 4.02.2014, poz. 118.

105 Tamże, s. 4.

106 Tamże, s. 6.

107 Por. tamże, s. 5-6. 
senioralnej poprawią jakość życia osób starszych w Polsce. Świadczy o tym poniższa deklaracja.

Planowane kierunki interwencji wynikają z kompleksowego ujęcia problematyki senioralnej, charakteryzującego się syntetycznym podejściem od strony merytorycznej oraz zintegrowanym od strony operacyjnej. W sferze merytorycznej należy objąć wsparciem aktualnie tego wymagające obszary (zatrudnienie, zdrowie i opieka, aktywność obywatelska i społeczna, edukacja i kultura) i zachować elastyczność wynikającą z możliwości otwierania się nowych. W wymiarze operacyjnym należy wziąć pod uwagę integrację i koordynację działań różnego typu podmiotów, mających bezpośredni kontakt z seniorami, jak i pośrednio oddziałujących na to środowisko, od jednostek administracji publicznej przez jednostki edukacyjne oraz kultury po organizacje i inicjatywy obywatelskie. Konieczna jest rozbudowa sieci tych podmiotów oraz wytworzenie mechanizmów współpracy, prowadzących także do popularyzacji tzw. dobrych praktyk. Równie istotne jest znaczne wzmocnienie infrastruktury dla tego typu działań.

Źródło: Założenia Dtugofalowej Polityki Senioralnej w Polsce na lata 20142020. Uchwała Rady Ministrów Rzeczypospolitej Polskiej z dnia 24 grudnia 2013, „Monitor Polski. Dziennik Urzędowy Rzeczypospolitej Polski” 4.02.2014, poz. 118 , s. 49 .

Przyjazne ustawodawstwo jest niezwykle potrzebne ze względu na demograficzne i społeczne uwarunkowania. Seniorzy muszą czuć, że państwo także w wymiarze prawnym nie marginalizuje starszego pokolenia. Co więcej, wspiera starszych w zmaganiu się z ograniczeniami wynikającymi z wieku, a jednocześnie przedstawia konkretne propozycje poprawiające zarówno ekonomiczną pozycję 
seniorów, jak i ich emocjonalne samopoczucie. Wydaje się, że przedstawione poniżej priorytety rządowe wychodzą naprzeciw oczekiwań osób starszych.

Realizacja Programu powinna możliwie szybko doprowadzić do tego, aby osoby starsze poczuły się pełnoprawną grupą społeczną, i zapobiec pojawiającemu się wykluczeniu społecznemu. W pierwszym rzędzie oznacza to:

1. szeroko rozumiane poczucie bezpieczeństwa (socjalne, zdrowotne, fizyczne, prawne i konsumenckie);

2. szansę nabywania niezbędnych we współczesnym świecie kompetencji, rozwijania zainteresowań oraz kreatywności;

3. możliwość integracji w wymiarze zarówno wewnątrz-, jak i międzypokoleniowym.

Kolejny etap to pełna partycypacja w sferze obywatelskiej i aktywność społeczna [...].

Elementem ważnym, a nawet kluczowym, warunkujacym odpowiedni efekt podczas realizacji polityki będzie jej bieżace $i$ cykliczne monitorowanie. Wskazane jest, aby oprócz jednostek formalnie za to odpowiedzialnych, brali $w$ tym udziat partnerzy spoteczni, w tym organizacje obywatelskie, podobnie jak to jest w przypadku tworzenia ZDPS przez Radę, w sktad której wchodzq przedstawiciele różnych resortów, urzędów i partnerów społecznych.

Źródło: Założenia Dtugofalowej Polityki Senioralnej w Polsce na lata 20142020. Uchwała Rady Ministrów Rzeczypospolitej Polskie z dnia 24 grudnia 2013, „Monitor Polski. Dziennik Urzędowy Rzeczypospolitej Polskiej” 4.02.2014, poz. 118 , s. 49.

\section{Rozwój placówek wspierających seniorów}

W większości badań i opracowywanych programów społecznych można wyczytać, iż 
„strategiczne kierunki przyszłej polityki społecznej obejmować muszą m.in.:

- promocję zdrowia i funkcjonalnej sprawności starzejących się ludzi,

- wydłużanie okresu aktywności zawodowej osób po 60 . roku życia,

- zapewnienie świadczeń i usług dobrej jakości adresowanej do osób starszych,

- gwarantowanie bezpieczeństwa dochodowego ludziom starym"108.

W konsekwencji nakłada to na struktury państwowe opracowanie programów dbających o:

- równy dostęp do zasobów instytucjonalnych,

- sprawiedliwe ich rozmieszczenie,

- wybór właściwego sposobu interwencji,

- zapewnienie dostępu do opieki długoterminowej,

- ochronę praw obywatelskich wszystkich seniorów, a zwłaszcza ubogich i niesprawnych ${ }^{109}$.

Jednym $\mathrm{z}$ istotnych segmentów powyższych postulatów jest troska o rozwój placówek wspierających seniorów. Trzeba pamiętać, że „wsparcie społeczne oznacza wszelką pomoc na rzecz jednostki lub grupy w sytuacjach trudnych, stresowych, przełomowych, których (jednostka lub grupa) samodzielnie nie byłaby w stanie przezwyciężyć"110. Do najważniejszych instytucji wspierających osoby starsze w Polsce należą przede wszystkim:

- domy pomocy społecznej (DPS), dzienne domy pomocy,

- kluby seniora,

108 Raport: Instytucje wobec potrzeb osób starszych. Raport opracował zespół Instytutu Rozwoju Służb Społecznych, Warszawa 2010, http://irss.pl/wp-content/uploads/2011/07/Instytucje-wobec-potrzeb-osob-starszych-raport-IRSS.pdf (20.02.2014).

109 Por. tamże.

110 S. Kawula, Wsparcie społeczne, [w:] Elementarne pojęcia pedagogiki społecznej i pracy socjalnej, red. D. Lalak, T. Pilch, Warszawa 1999, s. 338. 
- uniwersytety trzeciego wieku (UTW),

- hospicja,

- organizacje pozarządowe (Polski Komitet Pomocy Społecznej, Polski Czerwony Krzyż, Krajowa Centrala „Caritas", koła gospodyń wiejskich),

- działalność samopomocowa ${ }^{111}$.

Konieczne jest przyspieszenie realizacji postulatu zakładającego, że „instytucje państwowe, organizacje pozarządowe i środki masowego przekazu mają podjąć starania, aby osoby stare miały dostęp do wiedzy na różnym poziomie (w skali świata także do alfabetyzacji), aby nie musiały żyć z piętnem upośledzenia fizycznego czy psychicznego, a także nie były pozbawione zadań i uznania w swoim środowisku"112.

Podsumowując powyższe refleksje, należy stwierdzić, iż przed współczesnym społeczeństwem stoi wiele problemów natury gerontologicznej, które trzeba pilnie rozwiązać. Człowiek stary musi na nowo odnaleźć swoje miejsce w społeczeństwie, bowiem w dobie cywilizacji cyfrowej, technicyzacji życia łatwo zostać zmarginalizowanym.

Konkluzją refleksji nad gerontologicznymi wyzwaniami współczesnej cywilizacji mogą być słowa Jana Pawła II skierowane do seniorów: „Wy sami doświadczacie, że ten czas, gdy nie rozpraszają was już rozliczne zajęcia, może sprzyjać głębszej refleksji i dłuższemu dialogowi z Bogiem w modlitwie. Wasza dojrzałość pozwala wam też dzielić się z młodszymi mądrością zgromadzoną dzięki życiowym doświadczeniom, wspomagać ich w trudzie wzrastania oraz poświęcać im czas i uwagę w momencie, gdy otwierają się na przyszłość i szukają swojego miejsca w życiu. Możecie

111 Por. Z. Szarota, Gerontologia społeczna..., dz. cyt., s. 72-89.

112 H. Szwarc, Dwadzieścia pięć lat Uniwersytetu Trzeciego Wieku $w$ Warszawie, [w:] Ksiegga Jubileuszowa wydana $z$ okazji 25-lecia Uniwersytetu Trzeciego Wieku, red. H. Szwarc, Warszawa 2000, s. 8. 
odgrywać w ich życiu naprawdę cenną rolę"113. Zatem człowiek nie jest skazany na starość. Powinna ona być darem przyjmowanym z pogodą ducha.

\section{Bibliografia}

Benedykt XVI, Do uczestników XVIII Zgromadzenia Plenarnego Papieskiej Rady ds. Rodziny (15.04.2008), „L'Osservatore Romano” 29 (2008) nr 5, s. 28-30.

Benedykt XVI, Wizyta w Domu św. Piotra (Londyn, 18.09.2010), „L'Osservatore Romano” 31 (2010) nr 11, s. 35.

Brzezińska M., Ucieczka od życia, „Wspólne Tematy” 2006 nr 1112, s. 55-60.

Bywalec C., Rudnicki L., Konsumpcja, Warszawa 2002.

Chmielnicki N., Dziadkowie, babcie, wnuki, „Problemy Rodziny” 1978 nr 1, s. 29-35.

Cieślik M., Górny W., Bogdasiński M., Eutanazizm, „Wprost” 2004 nr 13, s. 58-60.

Ciura G., Szymańczak J., Starzenie się spoteczeństwa polskiego, „Infos. Zagadnienia Społeczno-Gospodarcze" 2012 nr 12, s. 1-4.

Czerniawska A., Drogi i bezdroża andragogiki i gerontologii, Łódź 2000.

Dąbrowska P., Samotność osób starszych $i$ sposoby jej przeciwdziałania, „Fides et Ratio” 2011 nr 2 (6), s. 84-90.

Derejczyk J., Bień B., Kokoszka-Paszkot J., Szczygieł J., Gerontologia $i$ geriatria $w$ Polsce na tle Europy - czy należy inwestować $w$ ich rozwój w naszym kraju?, „Gerontologia Polska” 16 (2008) nr 3, s. $146-159$.

Diagnoza społeczna 2011. Warunki życia Polaków. Raport Rady Monitoringu Społecznego, red. J. Czapiński, T. Panek, Warszawa 2011.

Dubas E., Edukacja dorostych w sytuacji samotności i osamotnienia, Łódź 2000.

113 Jan Paweł II, Jubileusz ludzi starszych (17.09.2000), dz. cyt., s. 17. 
Durda R., Dyskryminacja i przemoc wobec osób starszych, www.spr. org.pl/(20.02.2014).

Fenigsen R., Eutanazja. Śmierć z wyboru?, Poznań 1994.

Fromm E., Zdrowe społeczeństwo, tłum. A. Tanalska-Dulęba, Warszawa 1996.

Giddens A., Poza prawica i lewica, tłum. J. Serwański, Poznań 1994.

Gołębiewska I., Wspótczesna starość - czy można się do niej przygotować? „Cywilizacja” 2012 nr 42, s. 35-46.

Grzanka-Tykwińska A., Rzepka A., Chudzińska M. i in., Problematyka przemocy wobec osób starszych, „Nowiny Lekarskie” 81 (2012) nr 1, s. 44-48.

Havighurst R. J., Successful aging, [w:] Processes of aging, ed. R. H. Williams, C. Tibbits, W. Donahue, New York 1963, s. 299-320.

Hołyst B., Na granicy życia i śmierci, Warszawa 2007.

Hostyński L., Wartości w świecie konsumpcji, Lublin 2006.

Jan Paweł II, Do uczestników sesji plenarnej Papieskiej Akademii Nauk Społecznych (30.04.2004), „L'Osservatore Romano” 25 (2004) nr 7-8, s. 17-18.

Jan Paweł II, Do uczestników XIV Międzynarodowej Konferencji Papieskiej Rady ds. Duszpasterstwa Służby Zdrowia (19.11.1999), „L'Osservatore Romano” 21 (2000) nr 2, s. 43-44.

Jan Paweł II, Jubileusz ludzi starszych (17.09.2000), „L’Osservatore Romano” 21 (2000) 11-12, s. 33-34.

Jan Paweł II, List do moich Braci i Sióstr - ludzi w podeszłym wieku, Kraków 1999.

Jan Paweł II, List papieski do uczestników II Światowego Zgromadzenia poświęconego problemom starzenia się ludności, „L'Osservatore Romano" (2002) nr 6, s. 4-6.

Jan Paweł II, Rozważanie przed modlitwą „Anioł Pański” (Castel Gandolfo, 25.07.1999), „L'Osservatore Romano” 20 (1999) nr 11, s. 49. Jaroszewska E., Starość i agresja - osoby starsze jako ofiary oraz sprawcy przemocy, „Problemy Polityki Społecznej” 2012 nr 17, s. $113-129$.

Kaczmarczyk M., Trafiałek E., Aktywizacja osób starszych jako szansa na pomyślne starzenie się, „Gerontologia Polska” 15 (2007) nr 4, s. 116-118. 
Kawula S., Wsparcie spoteczne, [w:] Elementarne pojęcia pedagogiki społecznej i pracy socjalnej, red. D. Lalak, T. Pilch, Warszawa 1999, s. 338-341.

Kocimska P., Starość wyzwaniem dla wspótczesności, „Niebieska Linia" 2003 nr 5, s. 6-7.

Kotlarska-Michalska A., Starość w aspekcie socjologicznym, „Roczniki Socjologii Rodziny" 2000 t. 12, s. 147-159.

Krupa B., Starość w percepcji młodzieży - perspektywa pedagogiczna, „Nowiny Lekarskie” 81 (2012) nr 1, s. 36-43.

Krupińska S., Tobis S., Jakrzewska-Sawińska A., Wieczorkowska-Tobis K., Dlaczego boimy się starości?, „Geriatria” 2013 nr 7, s. 19-23.

Kuchcińska M., Edukacja przeciw marginalizacji seniorów, „Chowanna" 52 (2009) t. 2 (33), s. 173-186.

Kulik T. B., Janiszewska M., Piróg E. i in., Sytuacja zdrowotna osób starszych $w$ Polsce $i$ innych krajach europejskich, „Medycyna Ogólna i Nauki o Zdrowiu" 2011 nr 2, s. 90-95.

Łotocki Ł., Barwy jesieni. O społeczno-kulturowym obrazie starości, „Problemy Polityki Społecznej” 2012 nr 17, s. 131-146.

Mańczak J., Wykluczenie kulturowe - dysfunkcjonalność kulturowa ludzi starszych, [w:] Życie w starości, red. B. Bugajska, Szczecin 2007, s. 271-278.

Miłek T., Niekochana starość, „Przewodnik Katolicki” 2006 nr 40, s. 6-7.

Miszczak E., Problem samotności i osamotnienia wśród ludzi starszych w Polsce, [w:] Życie w starości, red. B. Bugajska, Szczecin 2007, s. 279-286.

Nizińska A., Uczenie się w dojrzałej i późnej dorostości, [w:] Silver team, czyli potęga doświadczenia. Poradnik trenera osób starszych, Wrocław 2013, s. 8-19.

Nowak A., Pojęcie, istota, przyczyny, mechanizmy marginalizacji i wykluczenia społecznego, „Chowanna” 55 (2012) t. 1 (38), s. 17-32.

Obuchowski K., Człowiek, dążenia, sens. Myśli wybrane, Bydgoszcz 2001. 
Osewska E., Rozwój religijności człowieka ze szczególnym uwzględnieniem rozwoju modlitwy, [w:] Dzisiejszy katecheta. Stan aktualny i wyzwania, red. J. Stala, Kraków 2002, s. 311-325.

Osiecka-Chojnacka J., Społeczne opinie o starości a wdrażanie idei aktywnego starzenia się, „Studia BAS” 2012 nr 2, s. 101-128.

Papiernik J., Samobójstwa osób starszych, www.zycie.senior.pl/147,0,Samobojstwa-osob-starszych,8425.html (12.02.2014).

Papież Franciszek, Audiencja dla kardynałów (15.03.2013), „L'Osservatore Romano" 34 (2013) nr 5, s. 10-11.

Papież Franciszek, Homilia w czasie mszy świętej w domu św. Marty (19.11.2013), http://gosc.pl/doc/1784844.Papiez-Ludzie-starsi-sa-zrodlem-madrosci (16.02.2014).

Pikuła N., Traczykowska E., Etos starości w aspekcie społecznym, Kraków 2011.

Piotrowski J., Miejsce człowieka starego $w$ rodzinie $i$ społeczeństwie, Warszawa 1973.

Plak J., Różne oblicza samotności seniora, „Pedagogia Ojcostwa” 2012 nr 5 (1), s. 256-267.

Przemoc $w$ rodzinie wobec osób starszych $i$ niepetnosprawnych. Raport z badania ogólnopolskiego (zespół projektu pod kierunkiem dr. hab. K. Korzeniowskiego), Warszawa 2009, s. 80.

Przygoda W., Formacja apostolska ludzi w podeszłym wieku, „Perspectiva" 8 (2009) nr 1, s. 170-184.

Raport: Instytucje wobec potrzeb osób starszych. Raport opracował zespół Instytutu Rozwoju Służb Społecznych, Warszawa 2010, http://irss.pl/wp-content/uploads/2011/07/Instytucje-wobec-potrzeb-osob-starszych-raport-IRSS.pdf (20.02.2014).

Rybczyńska I., Jak być (kochana) babcia, Warszawa 1976.

Sadler W., The causes of loneliness, [w:] Psychology and personal growth, red. A. Arkoff, Boston 1988, s. 136-140.

Skowroński J., Złoty wiek życia czy zrezygnowana starość, „Kotwica” 2009 nr 5 (45), s. 14-17.

Stopińska-Pająk A., „Szkoła starości” - być, aby się uczyć, „Chowanna" 52 (2009) t. 2 (33), s. 11-24. 
Straś-Romanowska M., Starzenie się jako kontekst rozwoju duchowego człowieka, [w:] Ludzie starsi w trzecim tysiacleciu. Szanse - nadzieje - potrzeby, red. W. Wnuk, Wrocław 2002, s. 27-34.

Stuart-Hamilton I., Psychologia starzenia się, tłum. A. Błachnio, Poznań 2006.

Surdykowski J., Starość, „Znak” 2007 nr 3, s. 140-148.

Sygit E., Ossowski R., Przemoc wobec osób starszych ze względu na ich wiek, płeć $i$ wyksztatcenie, „Geriatria Polska” 2008 nr 3, s. $163-168$.

Synak B., Starość w obliczu wspótczesnych przemian społeczno-kulturowych, [w:] Człowiek w obliczu starości, red. W. Pałubicki, Gdańsk 1991, s. 5-16.

Szarota Z., Gerontologia społeczna i oświatowa, Kraków 2004.

Szarota Z., Seniorzy w przestrzeni kulturalno-edukacyjnej społeczeństwa wiedzy, „Chowanna” 52 (2009) t. 2 (33), s. 77-96.

Szatur-Jaworska B., Błędowski P., Dzięgielewska M., Podstawy gerontologii społecznej, Warszawa 2006.

Szukalski P., Solidarność pokoleń. Dylematy relacji międzypokoleniowych, Łódź 2012.

Szukalski P., Uprzedzenia i dyskryminacja ze względu na wiek (ageizm) - przyczyny, przejawy, konsekwencje, „Polityka Społeczna” 2004 nr 2, s. 11-15.

Szwarc H., Dwadzieścia pięć lat Uniwersytetu Trzeciego Wieku $w$ Warszawie, [w:] Ksiega Jubileuszowa wydana z okazji 25-lecia Uniwersytetu Trzeciego Wieku, red. H. Szwarc, Warszawa 2000, s. 7-21.

Trafiałek E., Polska starość w dobie przemian, Katowice 2003.

Truchlińska B., Myśl antropologiczno-aksjologiczna Viktora E. Frankla, „Parerga” 2005 nr 2, s. 133-148.

Wołodźko E., Depresja u ludzi starszych, zdrowie.gazeta.pl/Zdrowie/1,105806,10491042,Depresja_u_ludzi_starszych.html (15.02.2014).

Z poradnika „Przemoc wobec osoby starszej”, www.kampaniaprzemoc.pl/ przemoc_wobec_osob_starszych.php (15.02.2014).

Założenia Dtugofalowej Polityki Senioralnej w Polsce na lata 20142020. Uchwała Rady Ministrów Rzeczypospolitej Polskiej z dnia 
24 grudnia 2013, „Monitor Polski. Dziennik Urzędowy Rzeczypospolitej Polski” 4.02.2014, poz. 118.

Zapędowska K., Polityka społeczna wobec osób starszych - utopia czy

konieczność, http://liberte.pl/polityka-spoleczna-wobec-osob-starszych-utopia-czy-koniecznosc (20.02.2014).

Zaworska-Nikoniuk D., Obszary zainteresowań pedagogów społecznych, Olsztyn 2002.

Zielińska-Więczkowska H., Kędziora-Kornatowska K., Kornatowski

T., Starość jako wyzwanie, „Gerontologia Polska” 16 (2008) nr 3, s. $131-136$.

Zielonka T. M., Na marginesie Kodeksu etyki lekarskiej, „Gazeta Lekarska" 2000 nr 3, s. 20-22.

Zych A. A., Stownik gerontologii społecznej, Warszawa 2001.

\section{Streszczenie}

Jednym z niepokojących problemów związanych z globalizacją zjawisk społecznych jest miejsce we współczesnym świecie osób starszych. Świat współczesny niejednokrotnie „ukrywa” ze wstydem kwestie starzejącego się społeczeństwa. W tym kontekście należy wymienić przynajmniej dziewięć problemów natury gerontologicznej, które warto omówić. Zaliczyć do nich można: juwenizm, marginalizacjaę osób starszych, samotność, „ekonomiczną eutanazję”, problemy przemocowe, samobójstwa i depresje osób starszych, problemy w pełnieniu ról przez starszych, ich aktywizację oraz problemy religijne wieku starczego. Współczesna cywilizacja musi zetknąć się z wieloma problemami związanymi z procesem starzenia się społeczeństw. Na koniec warto podać kilka kierunków rozwiązania tych problemów. Są to: afirmacja edukacji seniorów, troska o kompetencje kadr gerontologicznych, zmiana stylu życia seniorów, inkluzja społeczna seniorów, destereotypizacja starości, wychowanie do starości, przyjazne ustawodawstwo oraz rozwój placówek wspierających seniorów. 
Słowa kluczowe: gerontologia, współczesne wyzwania, kierunki pomocy, polityka senioralna

\section{Summary}

\section{Contemporary gerontological issues in the context of civilizational transformation}

One of the distressing problems associated with globalization of social phenomena is the place of the elderly in the modern world. The contemporary world often "hides" in shame issues of an aging population. In this context at least nine gerontological problems are worth to discuss. These include: juvenism, marginalization of older people, loneliness, "economic euthanasia", problems of violence, suicides and depression of the elderly, problems in fulfilling roles by the elders, their activation, and religious problems of old age. Modern civilization has encountered a number of problems associated with aging societies. Finally, some directions to solve these problems should be given. These are: affirmation of senior education; care of the competences of gerontological staff; seniors' lifestyle change; social inclusion of seniors, de-stereotyping of senility, education for old age, friendly legislation and the development of institutions supporting seniors.

Keywords: gerontology, contemporary challenges, directions of help, a senior policy

ks. Janusz Mastalski, Wspótczesne problemy gerontologiczne w kontekście cywilizacyjnych przemian, [w:] Pedagogiczne konteksty społecznego wsparcia rodziny, red. ks. Grzegorz Godawa, Kraków 2015, s. 111-178. 